\title{
Synthesis, Characterization and Catalytic Activities of Palladium Complexes with Phenylene-bridged Bis(thione) Ligands
}

Wei-Guo Jia, ${ }^{\text {a }}$ Li-Li Gao, ${ }^{a}$ Zhi-Bao Wang, ${ }^{a}$ Li-Ying Sun, ${ }^{\mathrm{b}}$ and Ying-Feng Han ${ }^{* b}$

a: College of Chemistry and Materials Science, The Key Laboratory of Functional Molecular Solids, Ministry of Education, Anhui Laboratory of Molecular-Based Materials (State Key Laboratory Cultivation Base), Anhui Normal University, Wuhu, 241002, China; *Corresponding author. E-mail: wgjiasy@mail.ahnu.edu.cn (W. -G. $\mathrm{Jia)}$

b: Key Laboratory of Synthetic and Natural Functional Molecular Chemistry of Ministry of Education, College of Chemistry and Materials Science, Northwest University, Xi’an 710127, P. R. China. E-mail: yfhan@nwu.edu.cn (Y. -F. Han)

\section{Contents}

1. Table S1 Crystallographic data and structure refinement parameters for palladium complexes (S2)

2. Copies of ${ }^{1} \mathrm{H},{ }^{13} \mathrm{C}$ NMR Spectra of 1a-1c (S3-S5).

3. Copies of ${ }^{1} \mathrm{H},{ }^{13} \mathrm{C}$ NMR Spectra of 2a-2c (S6-S9).

4. Copies of ${ }^{1} \mathrm{H},{ }^{13} \mathrm{C}$ NMR and 2D Spectra of palladium complexes 3a-3c (S10-S15).

5. Copies of ${ }^{1} \mathrm{H},{ }^{13} \mathrm{C}$ NMR and 2D Spectra of palladium complexes 4a-4c (S16-S19).

6. Copies of ${ }^{1} \mathrm{H}$ NMR of 1,3-bis(imidazol-1-yl)benzene (S20).

7. ESI-MS spectra of palladium complexes 3a-3c and $\mathbf{4 a - 4 c}$ (S21-S22)

8. The loading amount of catalyst $\mathbf{4 b}$ for $p$-nitrophenol reduction (S22)

9. The absorption of ligands (S23). 
Table S1 Crystallographic data and structure refinement parameters for palladium complexes ${ }^{\text {a }}$

\begin{tabular}{|c|c|c|c|c|c|}
\hline & 3a & $\mathbf{3 b}$ & 3c & $4 a$ & 4c \\
\hline Empirical formula & $\mathrm{C}_{34} \mathrm{H}_{44} \mathrm{Cl}_{2} \mathrm{~N}_{8} \mathrm{O}_{2} \mathrm{PdS}_{4}$ & $\mathrm{C}_{42} \mathrm{H}_{60} \mathrm{Cl}_{2} \mathrm{~N}_{8} \mathrm{O}_{2} \mathrm{PdS}_{4}$ & $\mathrm{C}_{38} \mathrm{H}_{44} \mathrm{Cl}_{2} \mathrm{~N}_{8} \mathrm{O}_{2} \mathrm{PdS}_{4}$ & $\mathrm{C}_{17} \mathrm{H}_{21} \mathrm{ClN}_{4} \mathrm{OPdS}_{2}$ & $\mathrm{C}_{18} \mathrm{H}_{21} \mathrm{ClN}_{4} \mathrm{PdS}_{2}$ \\
\hline Formula weight & 902.31 & 1014.52 & 950.35 & 503.35 & 499.36 \\
\hline Temperature (K) & 203(2) & $296(2)$ & $296(2)$ & $173(2)$ & $296(2)$ \\
\hline Crystal syst., & Triclinic & Triclinic & Triclinic & Monoclinic & Monoclinic \\
\hline Space group & $P \overline{1}$ & $P^{\overline{1}}$ & $P \overline{1}$ & $P 21 / n$ & $P 21 / n$ \\
\hline $\mathrm{a}(\AA)$ & $8.246(3)$ & $9.9926(13)$ & $8.412(2)$ & $7.6439(6)$ & $14.187(2)$ \\
\hline b $(\AA)$ & $10.526(3)$ & $10.8067(14)$ & $10.592(3)$ & $22.5815(17)$ & $8.6309(12)$ \\
\hline c $(\AA)$ & $13.022(4)$ & $12.4533(16)$ & $13.282(3)$ & $11.6662(9)$ & $16.466(2)$ \\
\hline$\alpha\left(^{\circ}\right)$ & $69.350(4)$ & $111.909(2)$ & $69.742(4)$ & 90 & 90 \\
\hline$\beta\left(^{\circ}\right)$ & $88.256(5)$ & $93.532(2)$ & $89.986(4)$ & $100.1100(10)$ & $103.326(2)$ \\
\hline$\gamma\left(\left(^{\circ}\right)\right.$ & $75.965(4)$ & $100.927(2)$ & $75.831(4)$ & 90 & 90 \\
\hline Volume $\left(\AA^{3}\right), Z$ & $1024.2(6), 1$ & $1212.1(3), 1$ & $1071.8(5), 1$ & 1982.4(3), 4 & $1961.9(5), 4$ \\
\hline $\mathrm{D}_{\mathrm{c}}\left(\mathrm{mg} / \mathrm{m}^{3}\right)$ & 1.463 & 1.390 & 1.472 & 1.686 & 1.691 \\
\hline$\mu(\mathrm{Mo}-\mathrm{K} \alpha)\left(\mathrm{mm}^{-1}\right)$ & 0.828 & 0.708 & 0.796 & 1.296 & 1.305 \\
\hline $\mathrm{F}(000)$ & 464 & 528 & 488 & 1016 & 1008 \\
\hline$\theta$ range $\left({ }^{\circ}\right)$ & $2.13-26.00$ & $2.09-27.54$ & $1.64-27.42$ & $1.80-27.48$ & $1.71-27.03$ \\
\hline Reflections/unique & $6694 / 3920$ & $8844 / 5421$ & $7745 / 4794$ & $14248 / 4516$ & $13142 / 4248$ \\
\hline [R(int)] & {$[\mathrm{R}(\mathrm{int})=0.0184]$} & {$[\mathrm{R}(\mathrm{int})=0.0247]$} & {$[\mathrm{R}(\mathrm{int})=0.0182]$} & {$[\mathrm{R}($ int $)=0.0199]$} & {$[\mathrm{R}(\mathrm{int})=0.0298]$} \\
\hline Goodness-of-fit on $\mathrm{F}^{2}$ & 1.051 & 1.055 & 1.240 & 1.098 & 1.100 \\
\hline$R_{1}, w R_{2}[I>2 \sigma(I)]^{\mathrm{a}}$ & $\begin{array}{l}\mathrm{R} 1=0.0268 \\
\mathrm{wR} 2=0.0626\end{array}$ & $\begin{array}{l}\mathrm{R} 1=0.0390 \\
\mathrm{wR} 2=0.1011\end{array}$ & $\begin{array}{l}\mathrm{R} 1=0.0356 \\
\mathrm{wR} 2=0.1119\end{array}$ & $\begin{array}{l}\mathrm{R} 1=0.0233 \\
\mathrm{wR} 2=0.0628\end{array}$ & $\begin{array}{l}\mathrm{R} 1=0.0389 \\
\mathrm{wR} 2=0.1144\end{array}$ \\
\hline$R_{1}, w R_{2}$ (all data) & $\begin{array}{l}\mathrm{R} 1=0.0336 \\
\mathrm{wR} 2=0.0669\end{array}$ & $\begin{array}{l}\mathrm{R} 1=0.0555 \\
\mathrm{wR} 2=0.1130\end{array}$ & $\begin{array}{l}\mathrm{R} 1=0.0452 \\
\mathrm{wR} 2=0.1425\end{array}$ & $\begin{array}{l}\mathrm{R} 1=0.0260 \\
\mathrm{wR} 2=0.0643\end{array}$ & $\begin{array}{l}\mathrm{R} 1=0.0522 \\
\mathrm{wR} 2=0.1339\end{array}$ \\
\hline
\end{tabular}

${ }^{\mathrm{a}} \mathrm{R}_{1}=\Sigma|| F_{\mathrm{o}}|-| F_{\mathrm{c}}|| / \Sigma\left|F_{\mathrm{o}}\right| ; \mathrm{wR}_{2}=\left[\Sigma w\left(\left|F_{\mathrm{o}}{ }^{2}\right|-\left|F_{\mathrm{c}}{ }^{2}\right|\right)^{2} / \Sigma w\left|F_{\mathrm{o}}\right|^{2}\right]^{1 / 2}$. 

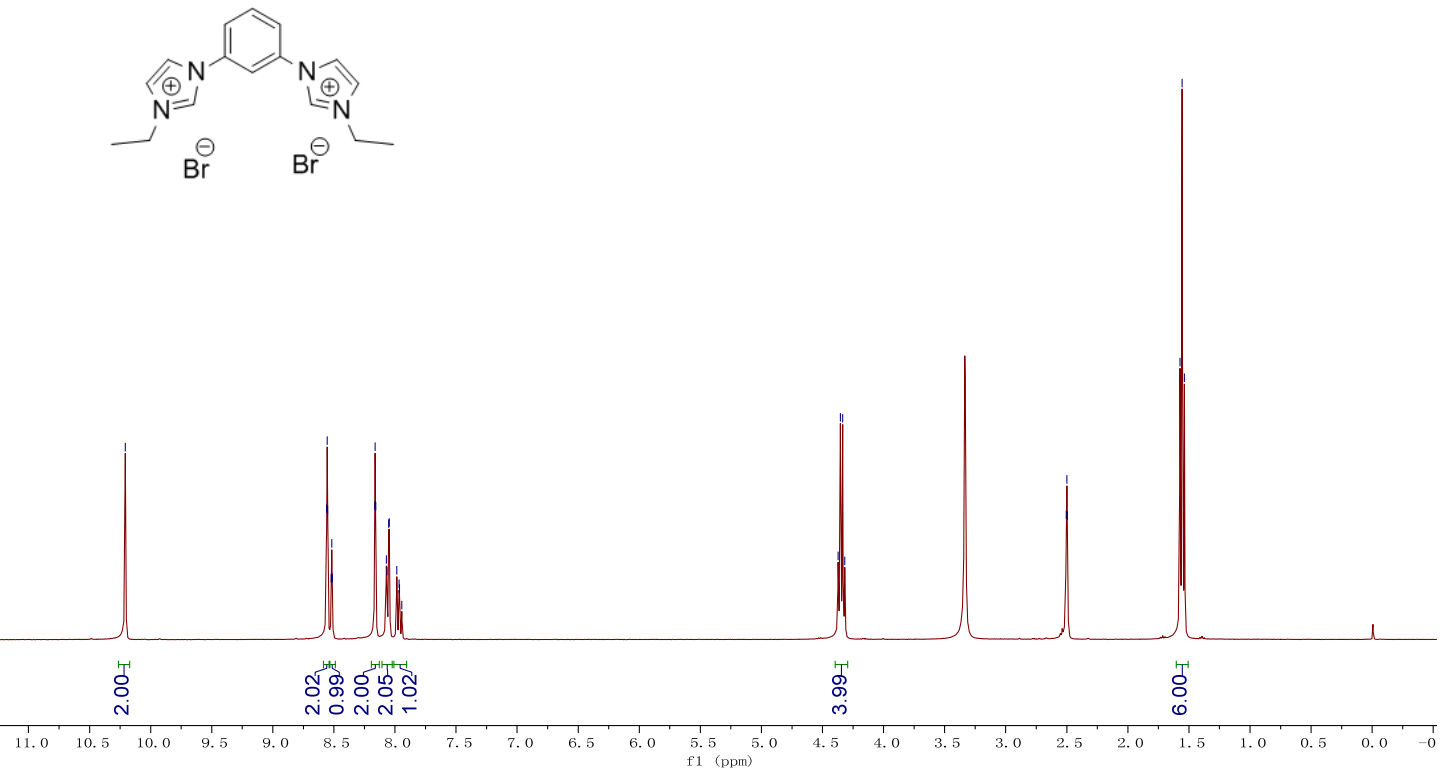

Figure S1. The ${ }^{1} \mathrm{H}$ NMR of 1a $\left(400 \mathrm{MHz}, \mathrm{DMSO}^{-\mathrm{d}_{6}}\right)$

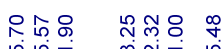

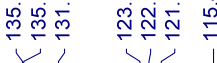

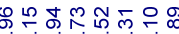

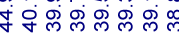

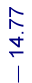
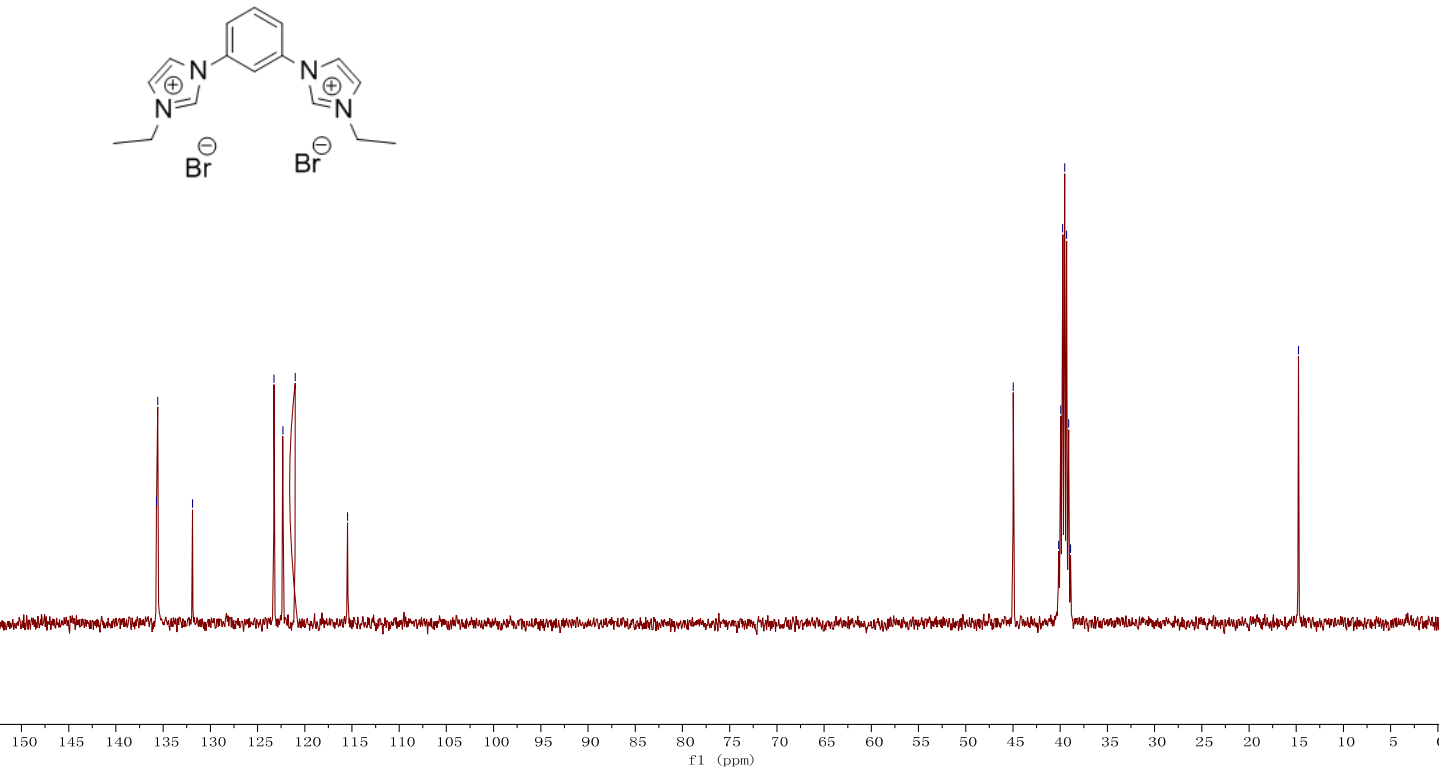

Figure S2. The ${ }^{13} \mathrm{C}$ NMR of $1 \mathbf{a}\left(100 \mathrm{MHz}, \mathrm{DMSO}-\mathrm{d}_{6}\right)$ 


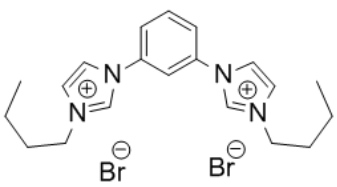

B

$\mathrm{Br}$
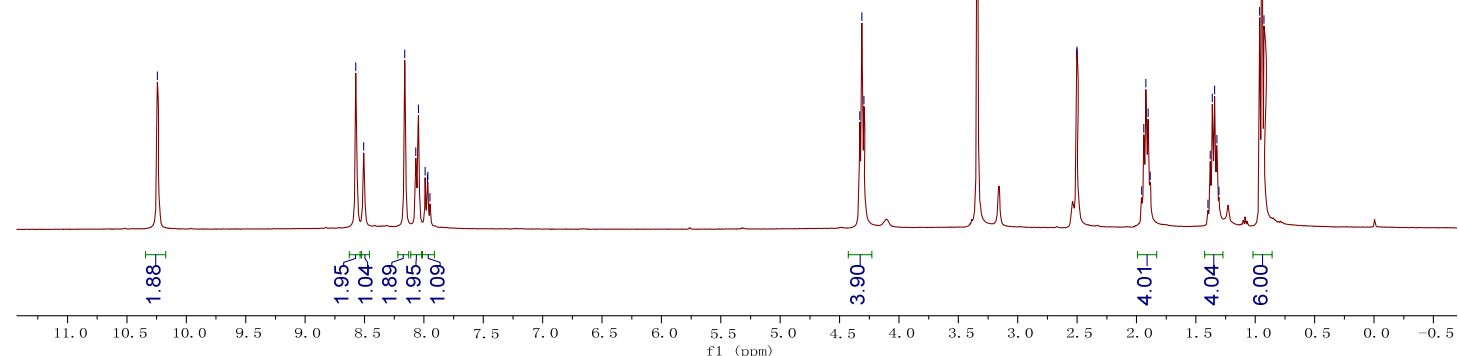

Figure S3. The ${ }^{1} \mathrm{H}$ NMR of $\mathbf{1 b}\left(400 \mathrm{MHz}, \mathrm{DMSO}^{\left.-\mathrm{d}_{6}\right)}\right.$

:

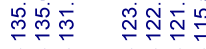

Q I I
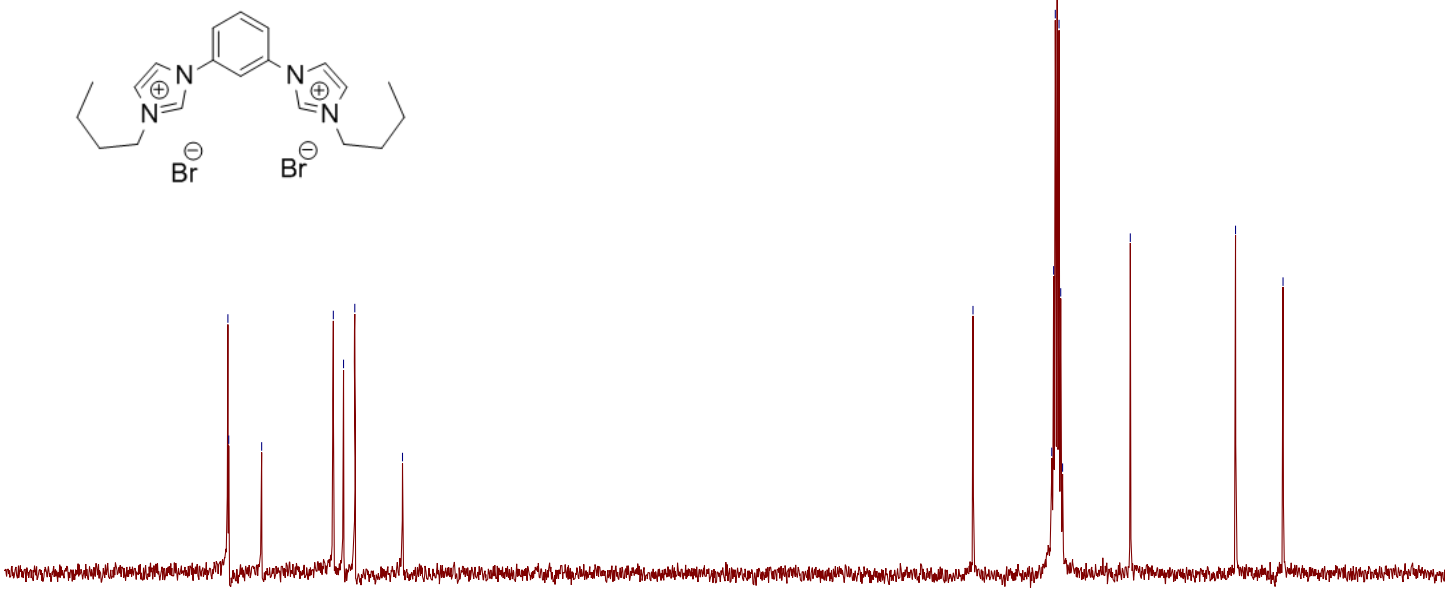

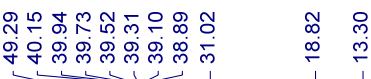

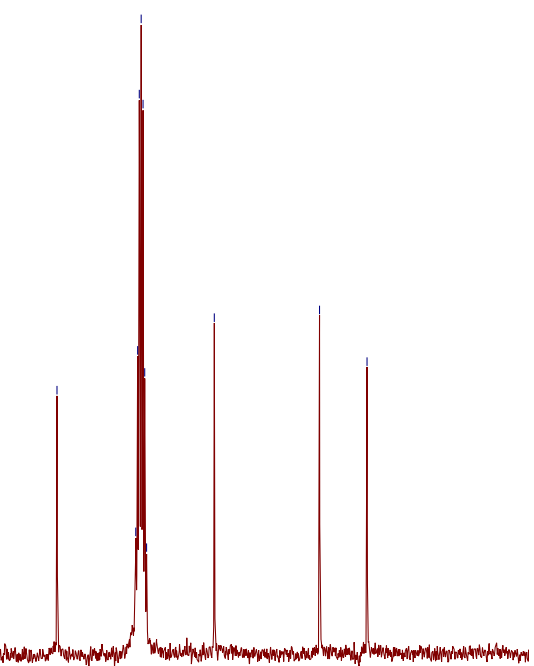

$\underset{160}{16}$ 80
$\mathrm{f} 1$

Figure S4. The ${ }^{13} \mathrm{C} N M R$ of $\mathbf{1 b}\left(100 \mathrm{MHz}, \mathrm{DMSO}-\mathrm{d}_{6}\right)$ 

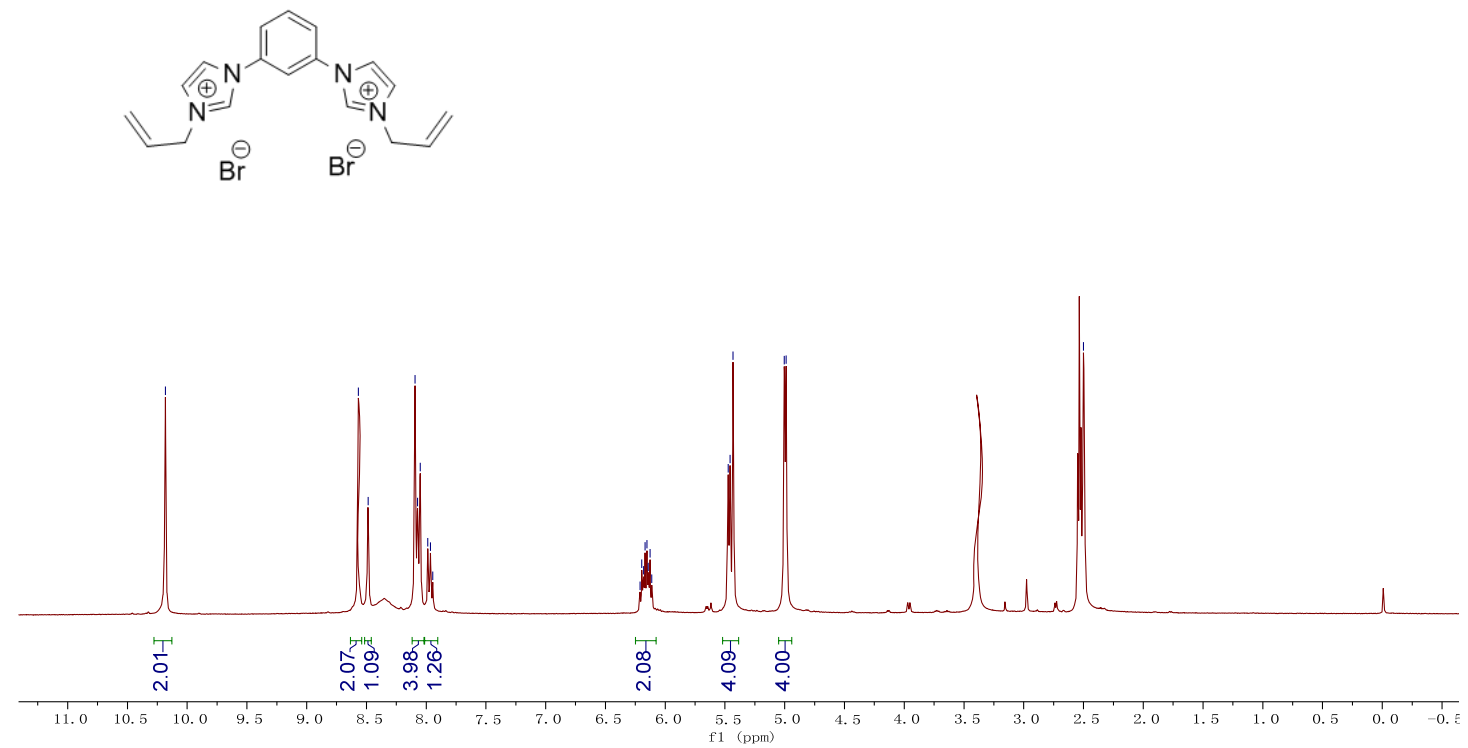

Figure S5. The ${ }^{1} \mathrm{H}$ NMR of $1 \mathrm{c}\left(400 \mathrm{MHz}, \mathrm{DMSO}-\mathrm{d}_{6}\right)$

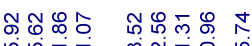

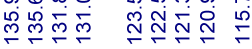

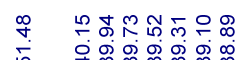

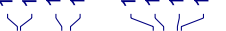

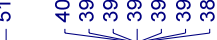
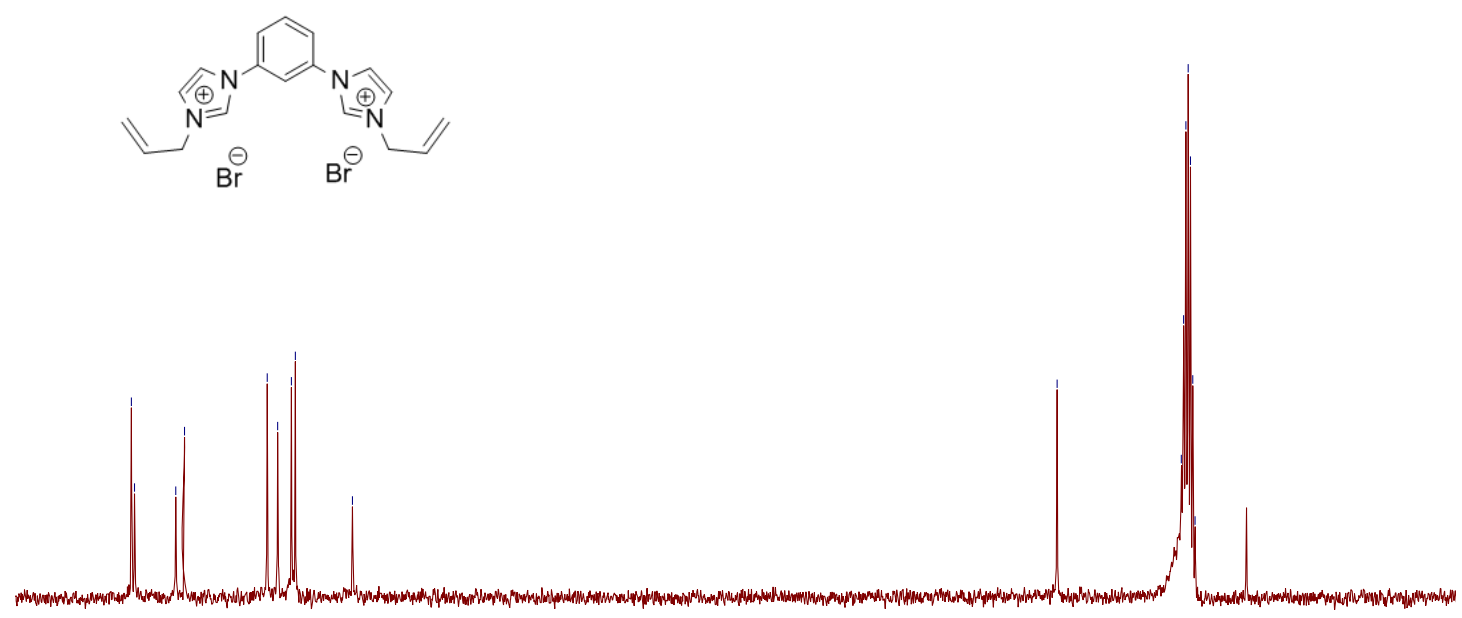

$145 \quad 140-135 \quad 130-125$

Figure S6. The ${ }^{13} \mathrm{C}$ NMR of $1 \mathrm{c}\left(100 \mathrm{MHz}\right.$, DMSO- $\left.\mathrm{d}_{6}\right)$ 


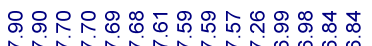

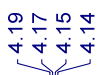

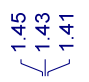
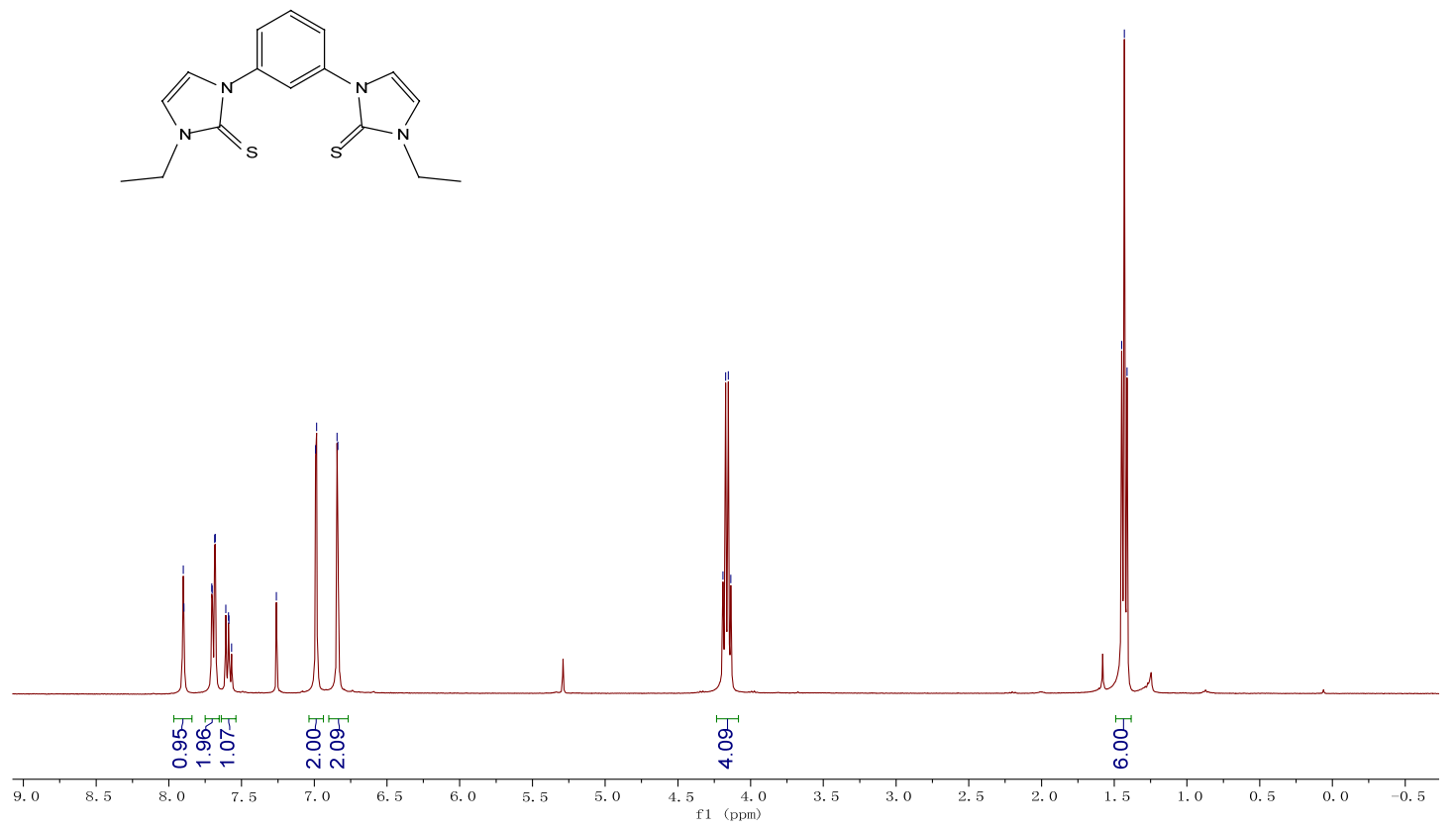

Figure S7. The ${ }^{1} \mathrm{H}$ NMR of $2 a\left(400 \mathrm{MHz}, \mathrm{CDCl}_{3}\right)$

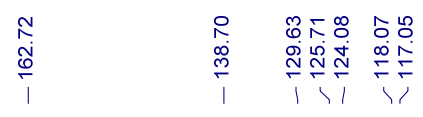

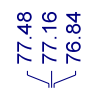

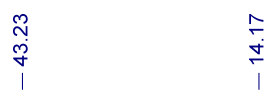
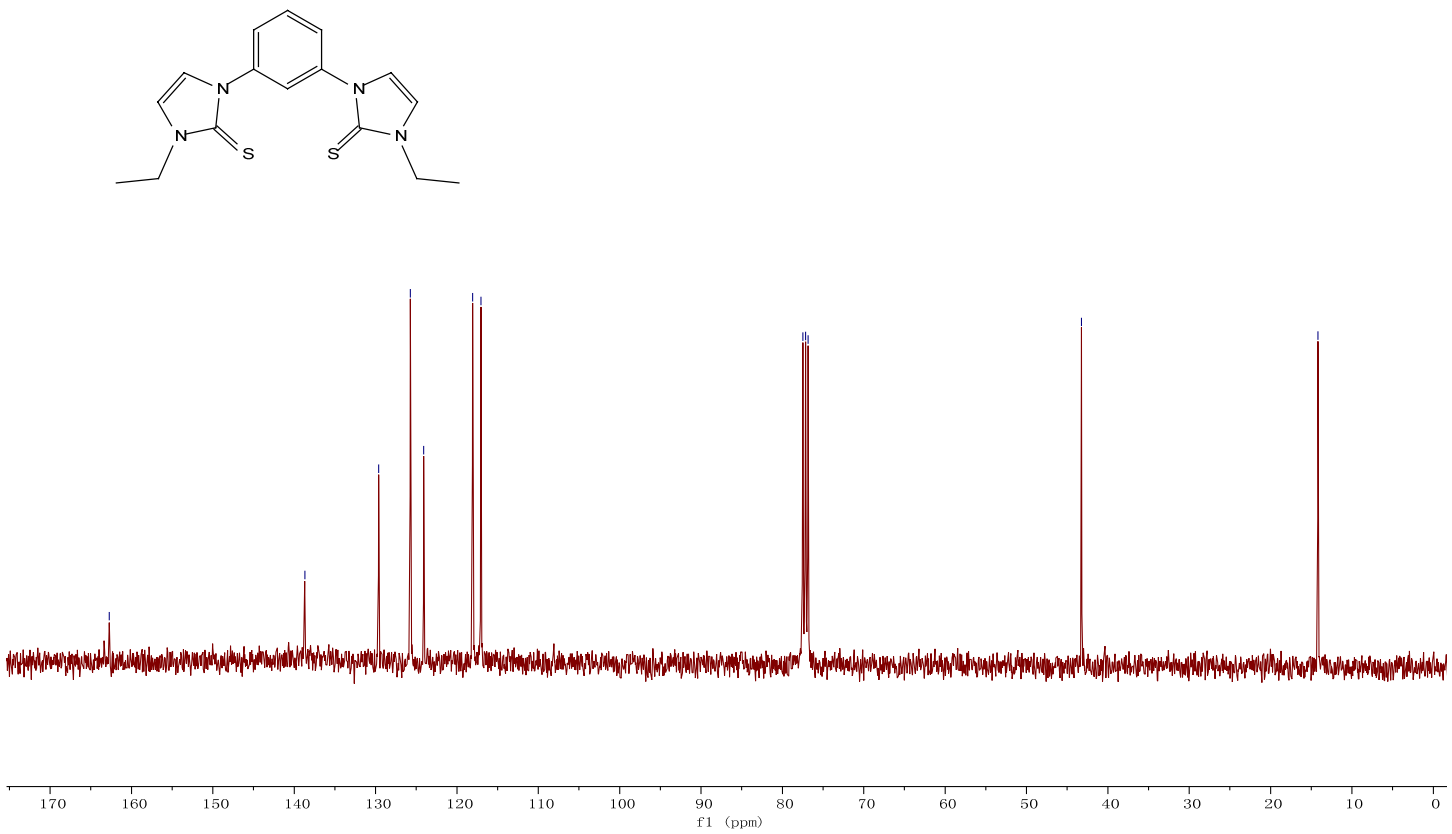

Figure S8. The ${ }^{13} \mathrm{C} N M R$ of $2 \mathbf{a}\left(100 \mathrm{MHz}, \mathrm{CDCl}_{3}\right)$

SG 

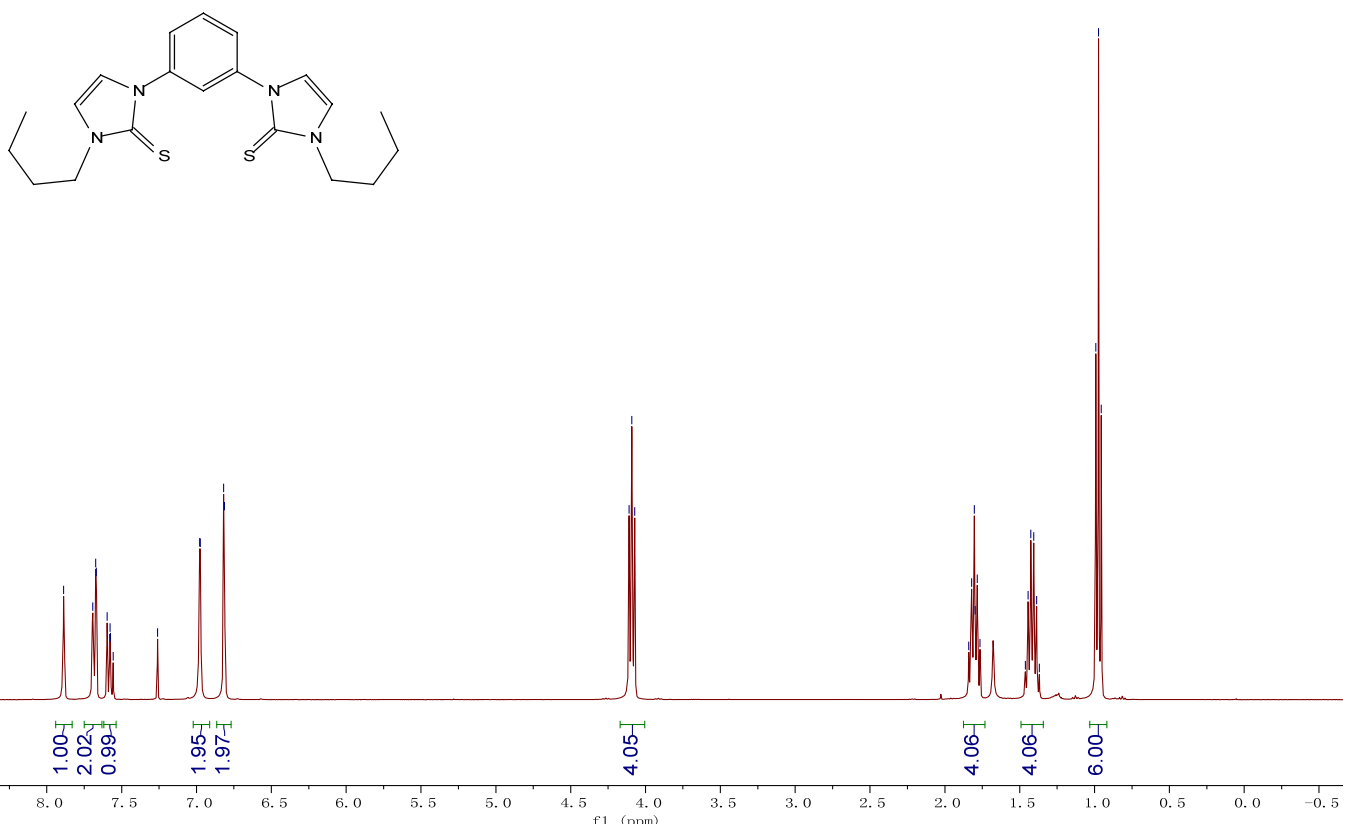

Figure S9. The ${ }^{1} \mathrm{H}$ NMR of $\mathbf{2 b}\left(400 \mathrm{MHz}, \mathrm{CDCl}_{3}\right)$

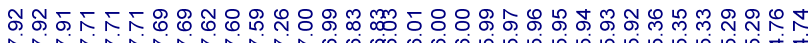

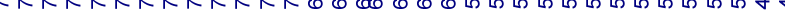<smiles>C=CCn1ccn(-c2cccc(-n3ccn(CC=C)c3=S)c2)c1=S</smiles>

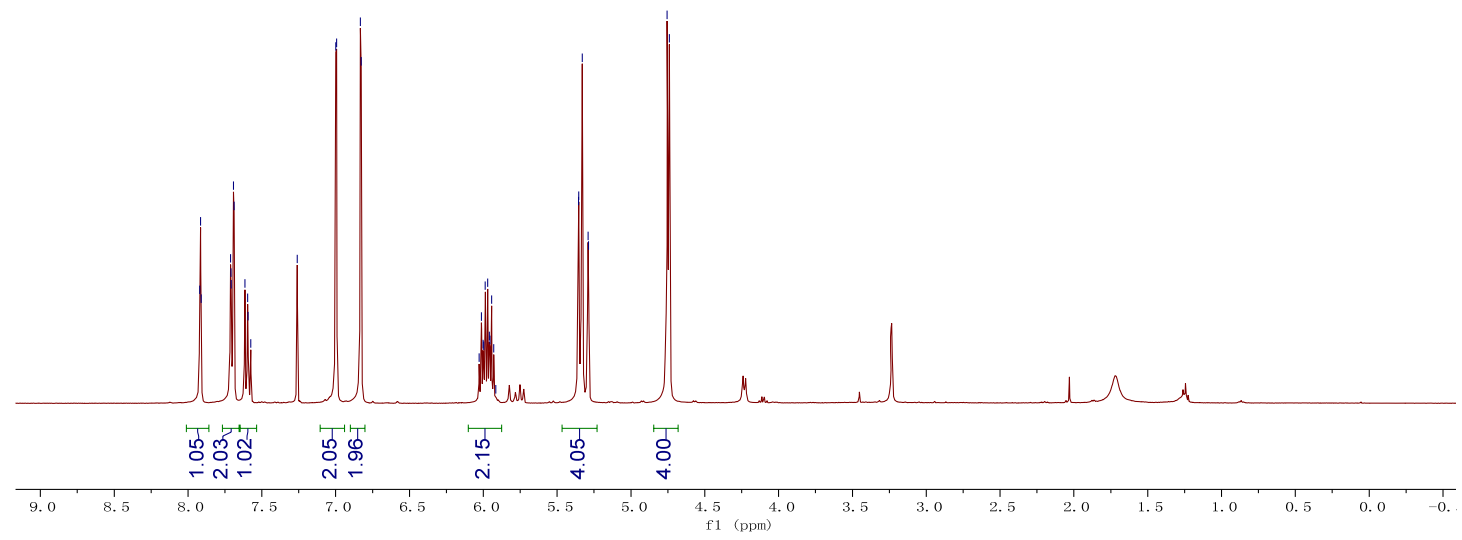

Figure S10. The ${ }^{1} \mathrm{H}$ NMR of $2 c\left(400 \mathrm{MHz}, \mathrm{CDCl}_{3}\right)$ 

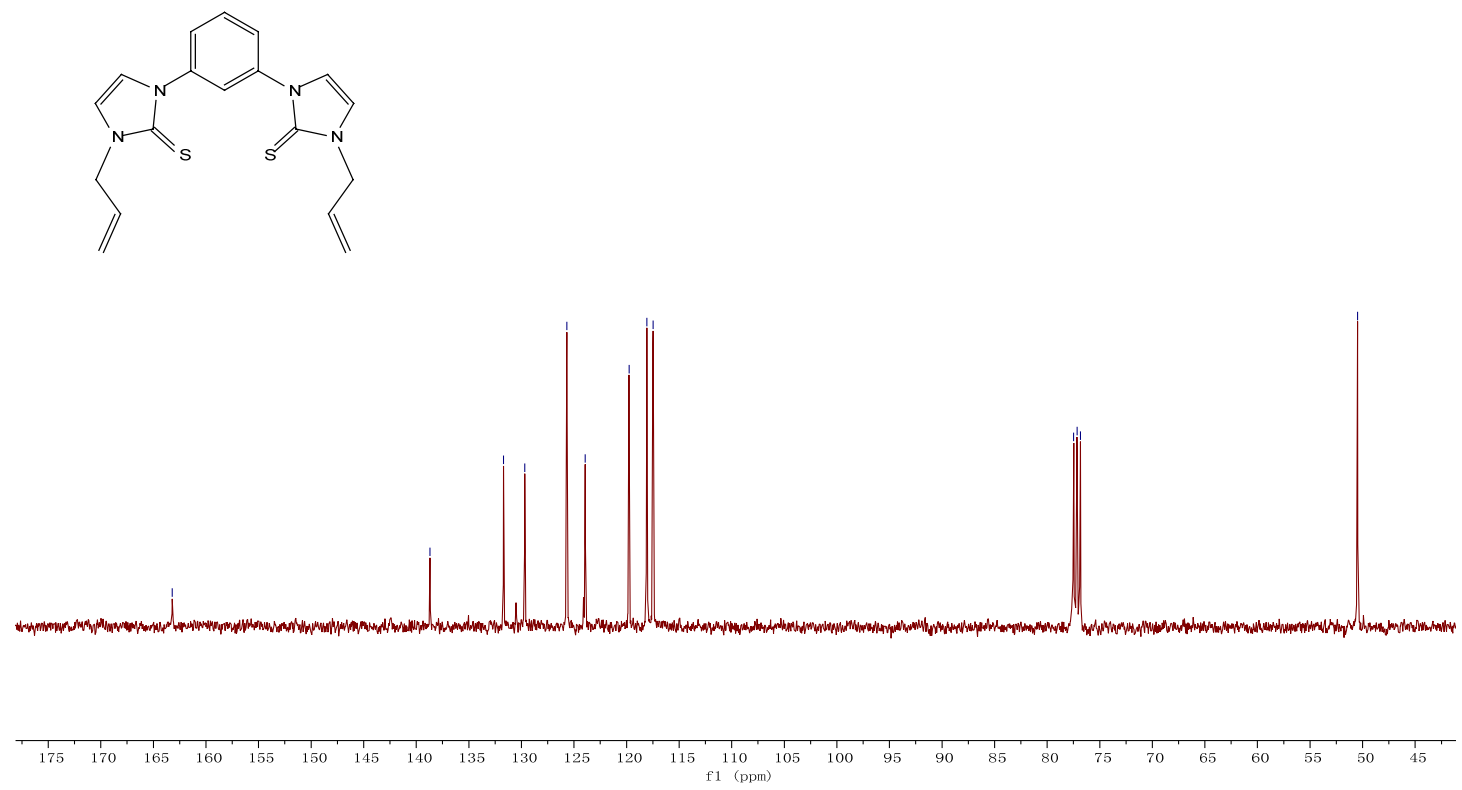

Figure S11. The ${ }^{13} \mathrm{C}$ NMR of $2 \mathrm{c}\left(100 \mathrm{MHz}, \mathrm{CDCl}_{3}\right)$

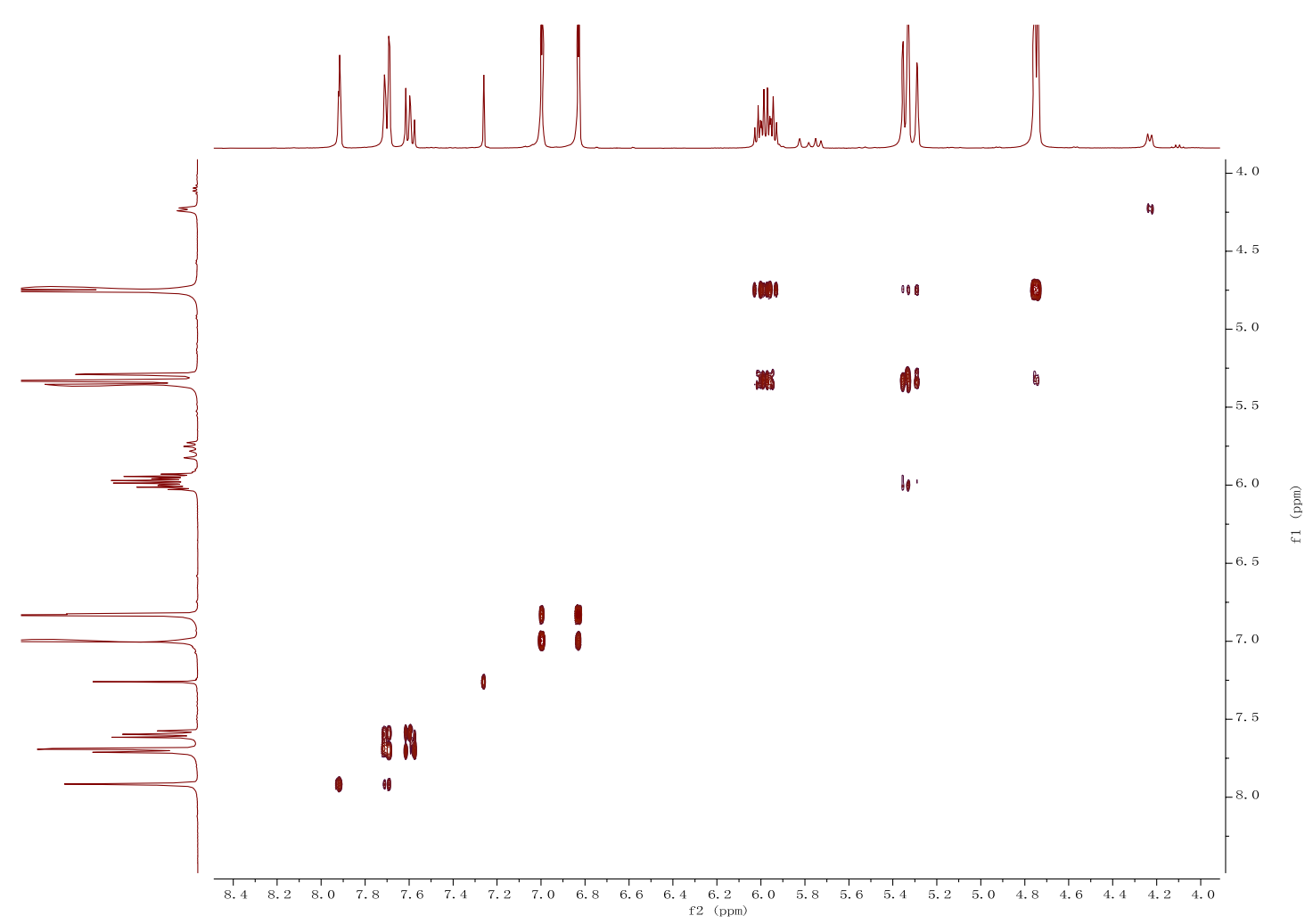

Figure S12. ${ }^{1} \mathrm{H}-{ }^{1} \mathrm{H}$ COSY Spectrum of $2 \mathrm{c}\left(400 \mathrm{MHz}, \mathrm{CDCl}_{3}\right)$ 


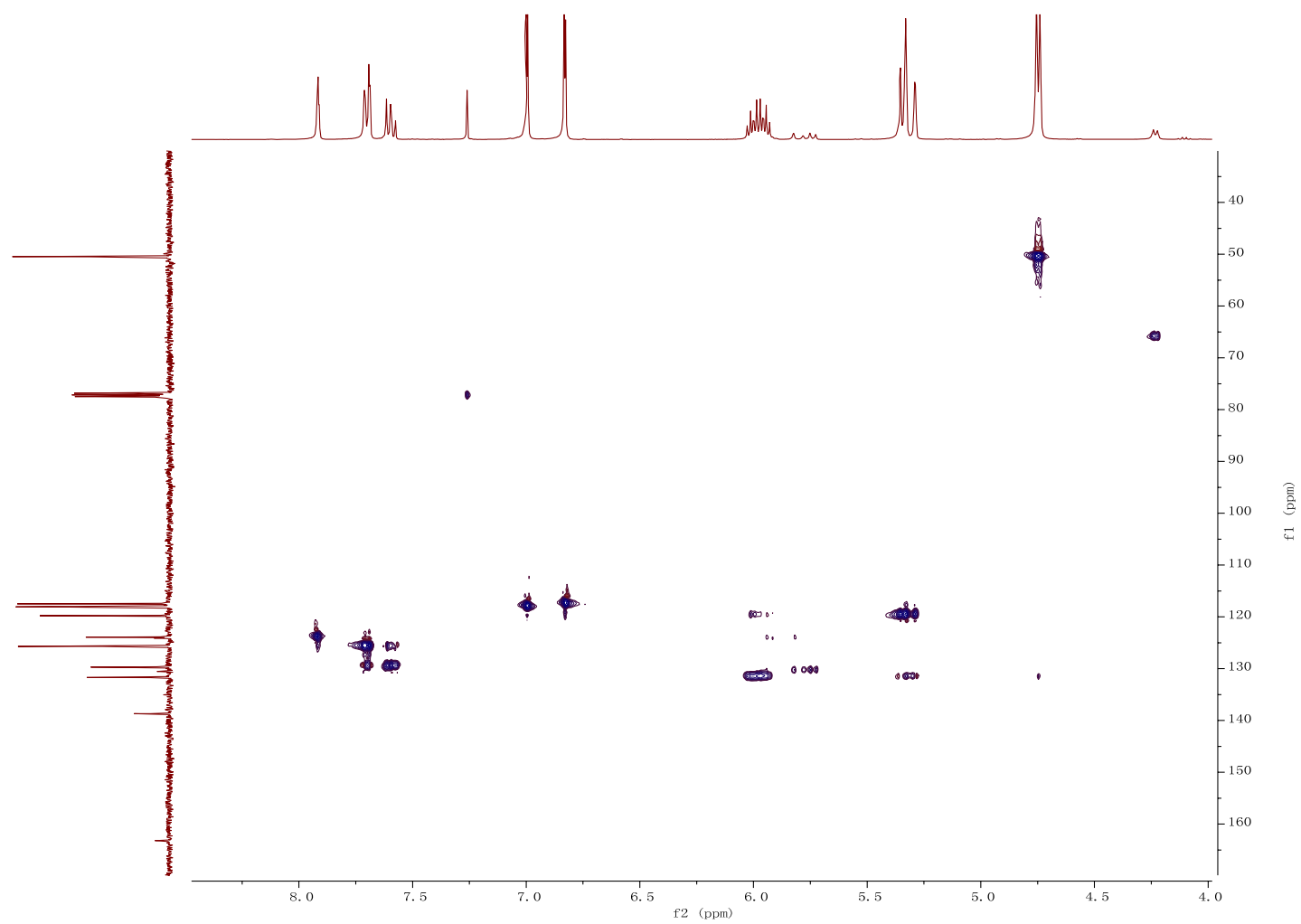

Figure S13. ${ }^{1} \mathrm{H}_{-}{ }^{13} \mathrm{C} \mathrm{HSQC} \mathrm{Spectrum} \mathrm{of} 2 \mathrm{c}\left(400 \mathrm{MHz}, \mathrm{CDCl}_{3}\right)$

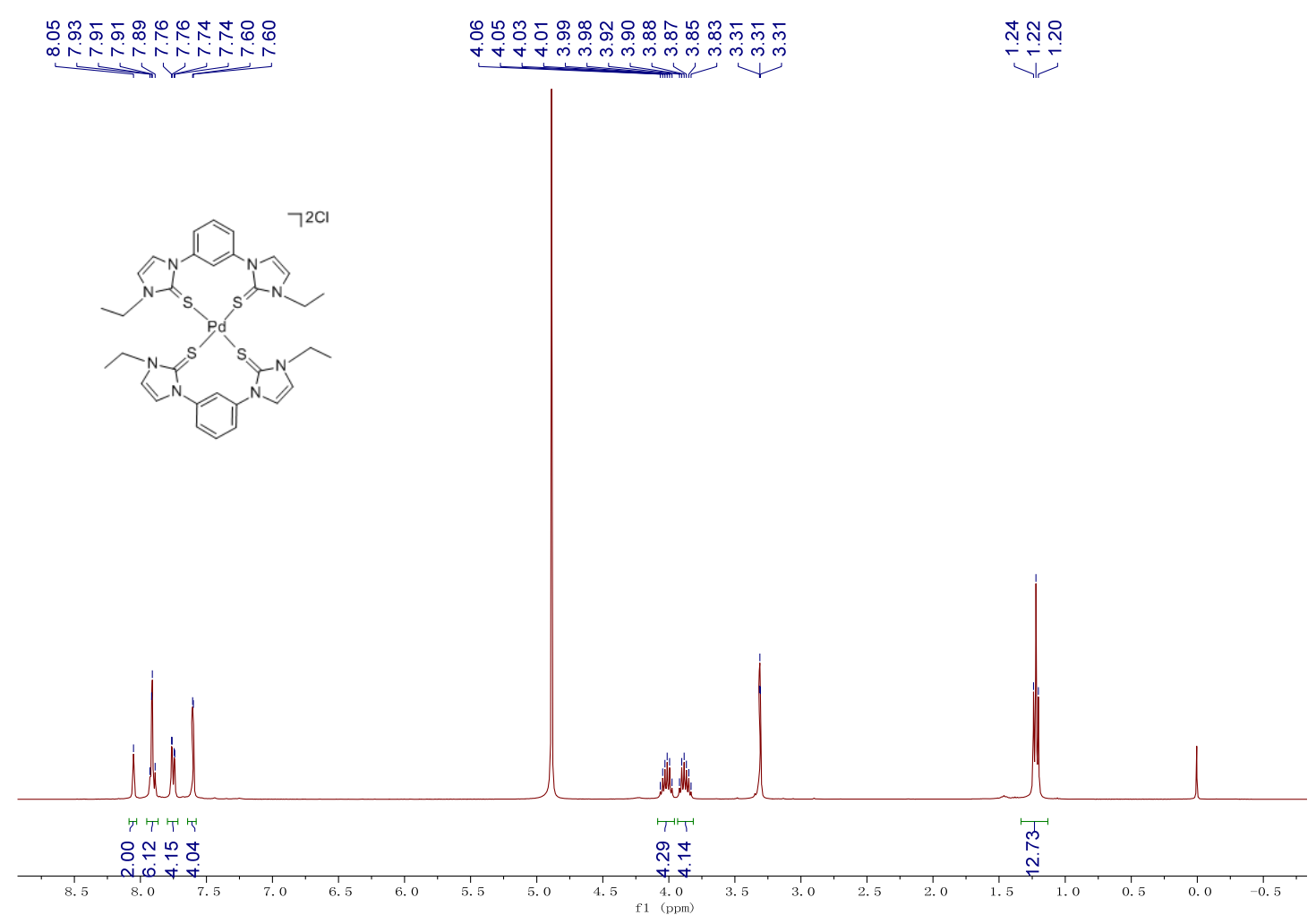

Figure S14. The ${ }^{1} \mathrm{H}$ NMR of 3a (400 MHz, MeOD- $\mathrm{d}_{4}$ ) 

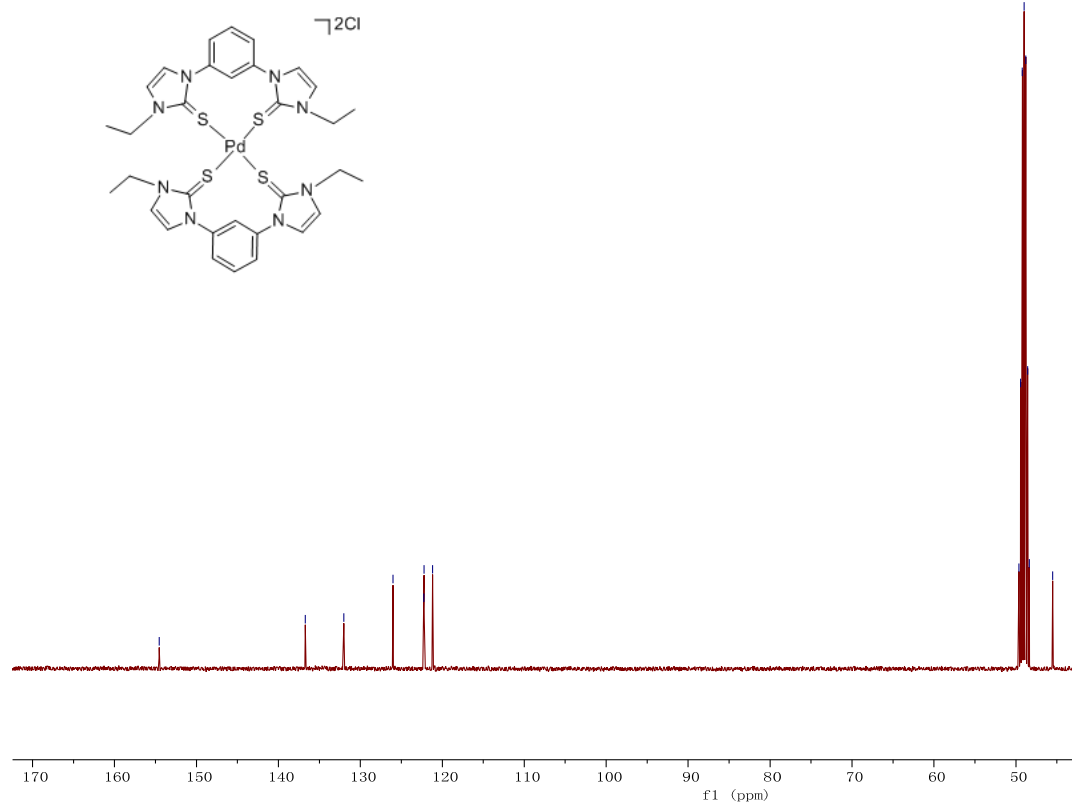

Figure S15. The ${ }^{13} \mathrm{C}$ NMR of 3a (100 MHz, MeOD- $\left.\mathrm{d}_{4}\right)$

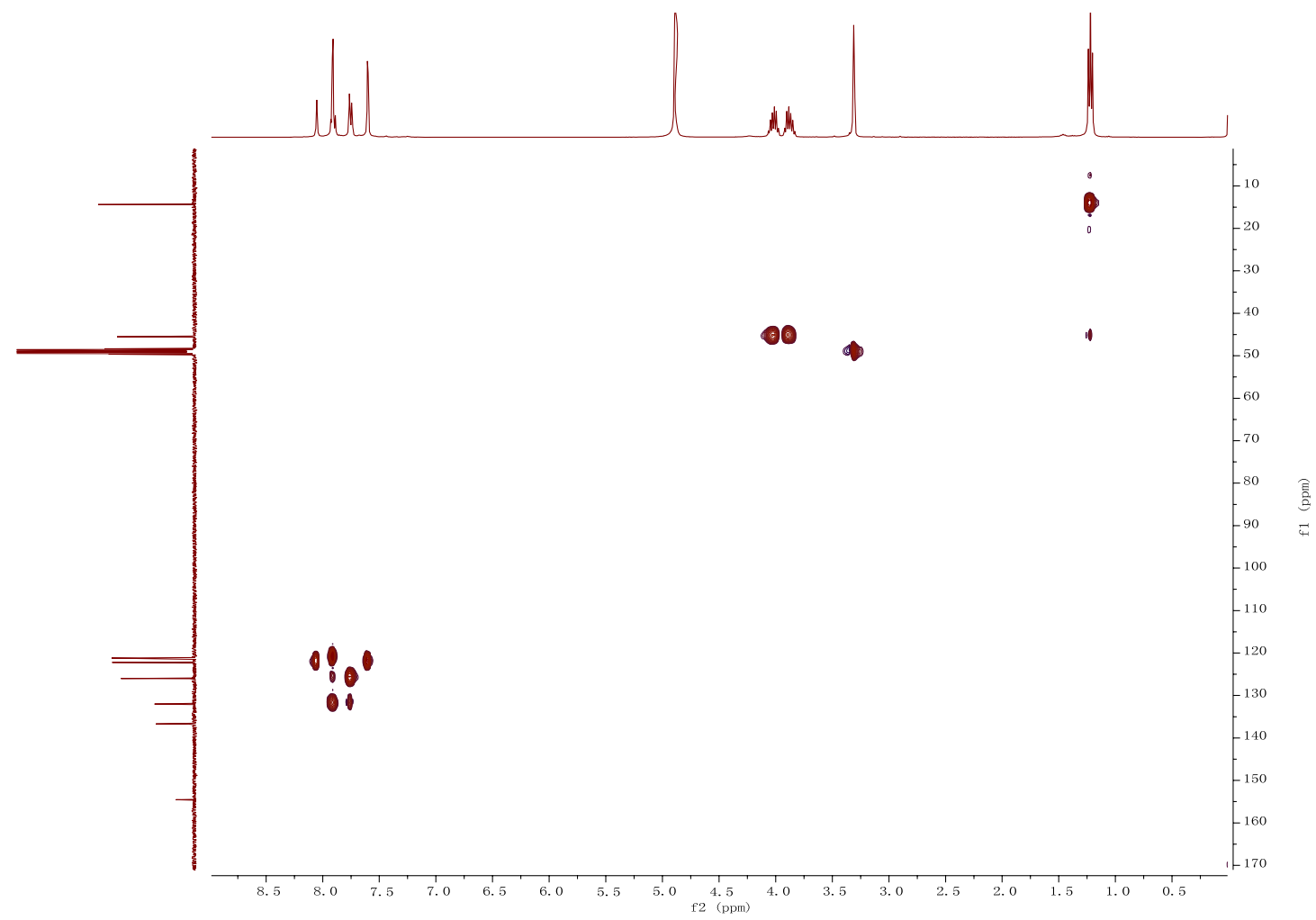

Figure S16. ${ }^{1} \mathrm{H}^{13} \mathrm{C}$ HSQC Spectrum of $3 a\left(400 \mathrm{MHz} / 100 \mathrm{MHz}, \mathrm{MeOD}-\mathrm{d}_{4}\right)$ 


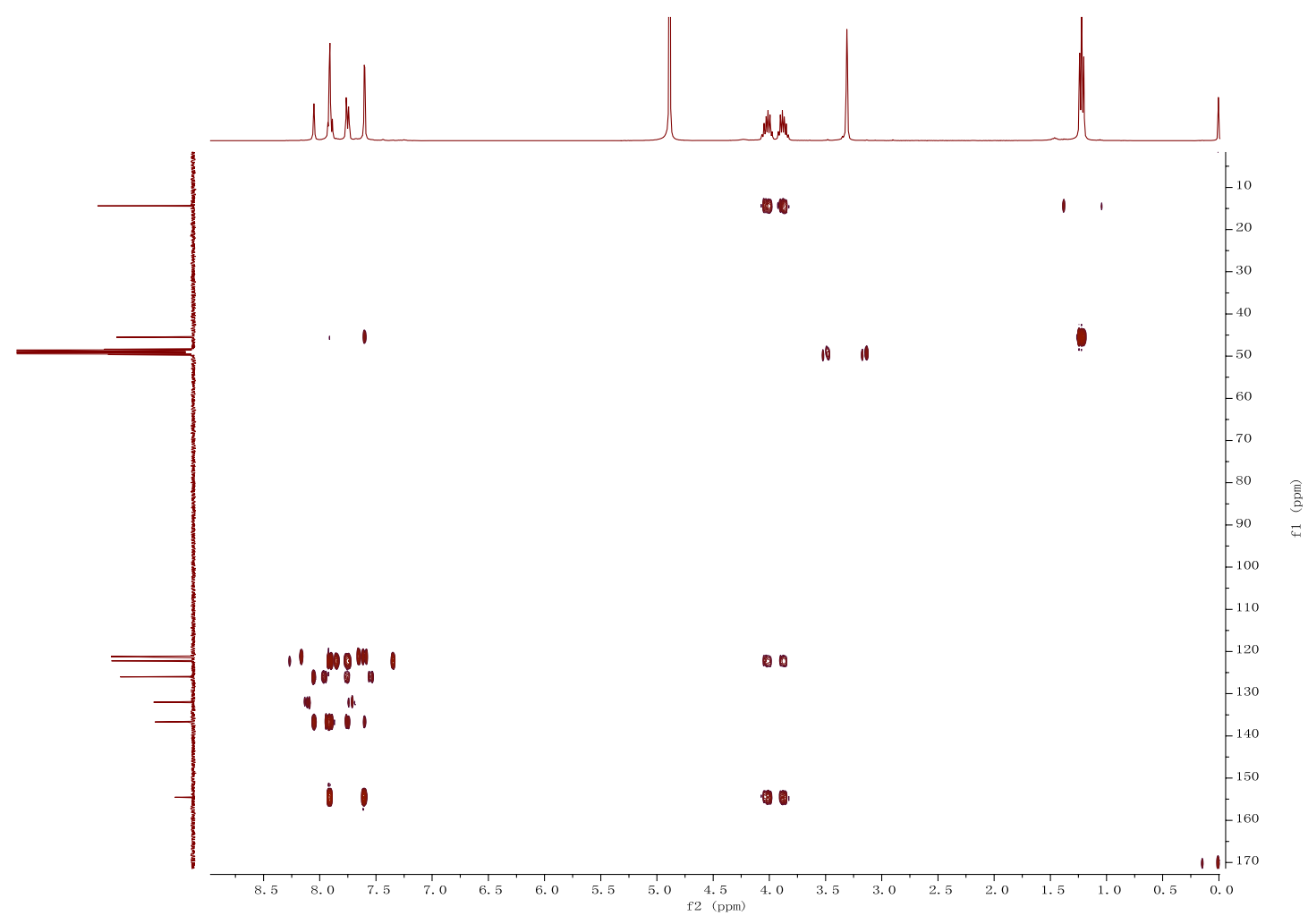

Figure S17. ${ }^{1} \mathrm{H}-{ }^{13} \mathrm{C}$ HMBC Spectrum of $3 a\left(400 \mathrm{MHz} / 100 \mathrm{MHz}, \mathrm{MeOD}-\mathrm{d}_{4}\right)$

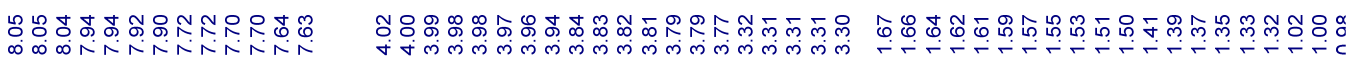

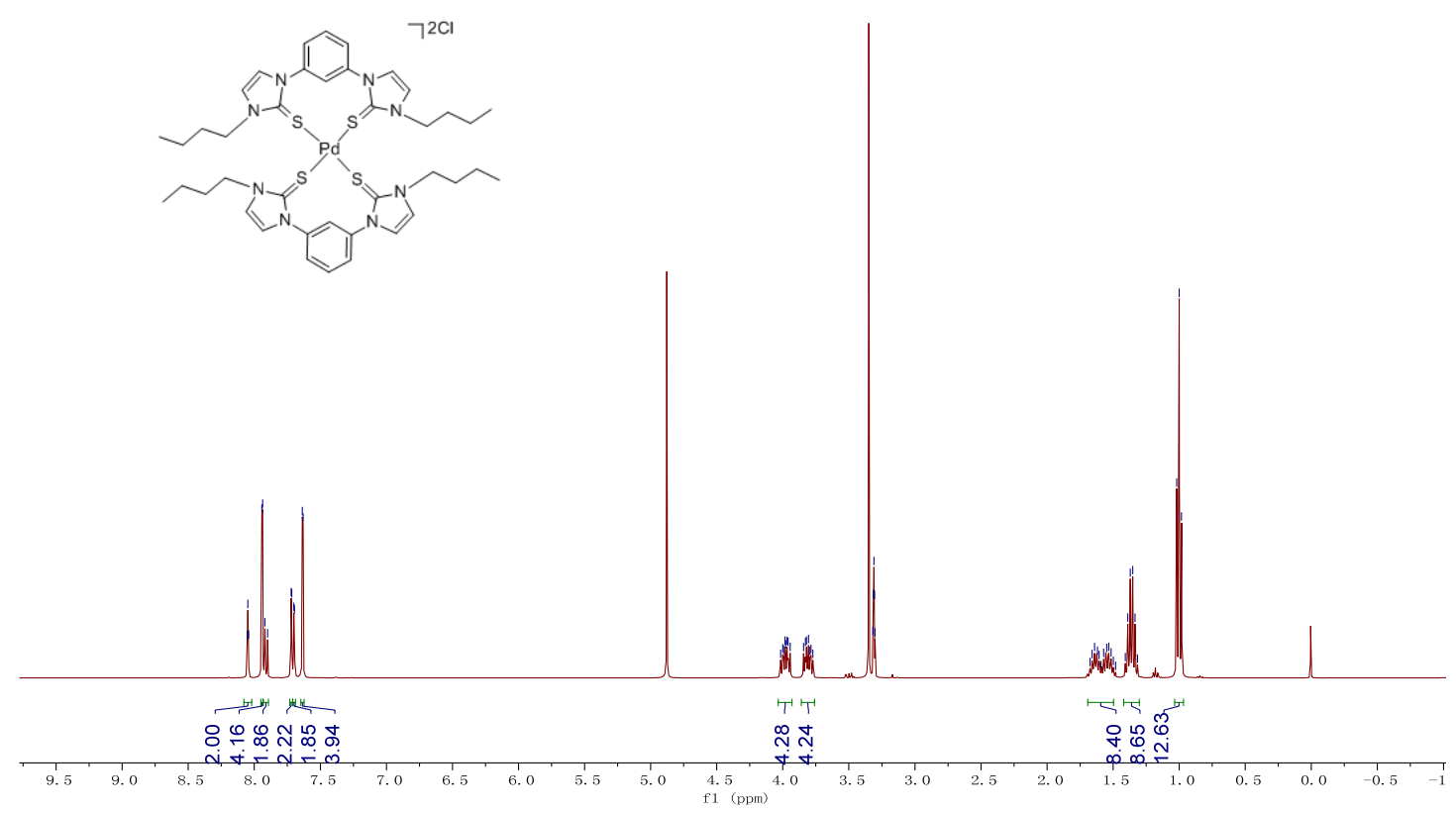

Figure S18. The ${ }^{1} \mathrm{H}$ NMR of $3 \mathbf{b}\left(400 \mathrm{MHz}, \mathrm{MeOD}-\mathrm{d}_{4}\right)$ 

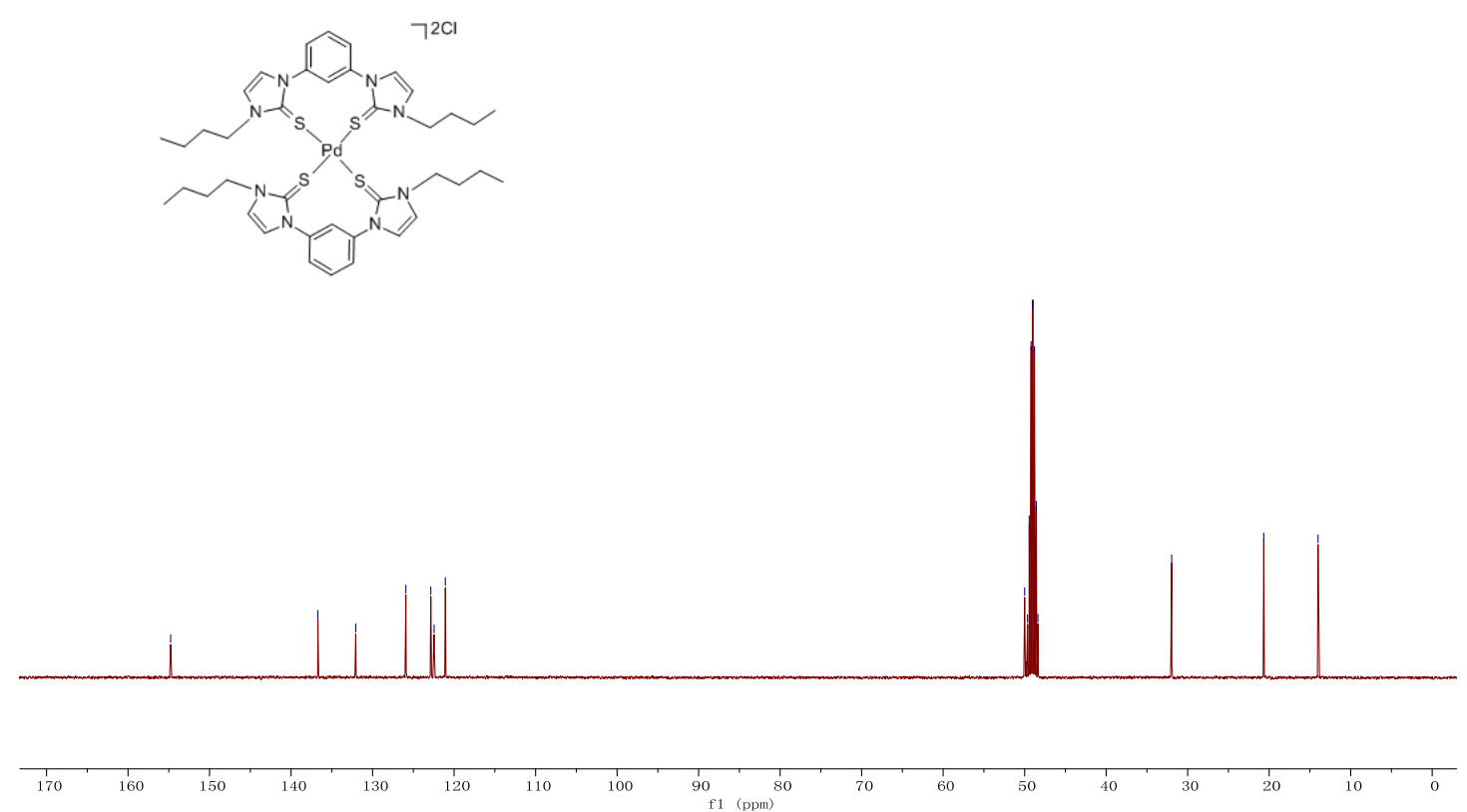

Figure S19. The ${ }^{13} \mathrm{C}$ NMR of $3 \mathbf{b}\left(100 \mathrm{MHz}, \mathrm{MeOD}-\mathrm{d}_{4}\right)$

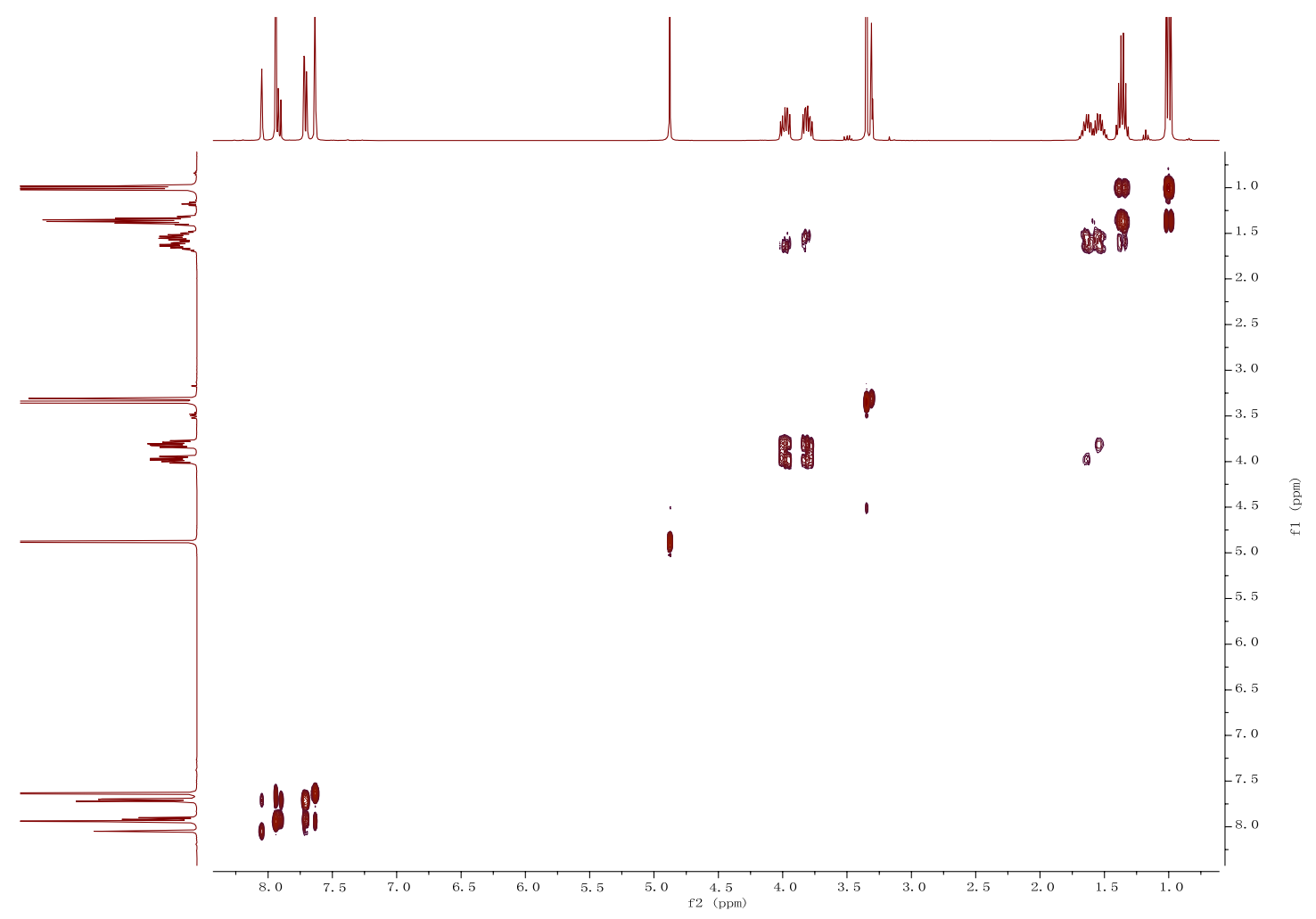

Figure S20. ${ }^{1} \mathrm{H}-{ }^{1} \mathrm{H}$ COSY Spectrum of $\mathbf{3 b}\left(400 \mathrm{MHz}, \mathrm{MeOD}-\mathrm{d}_{4}\right)$ 


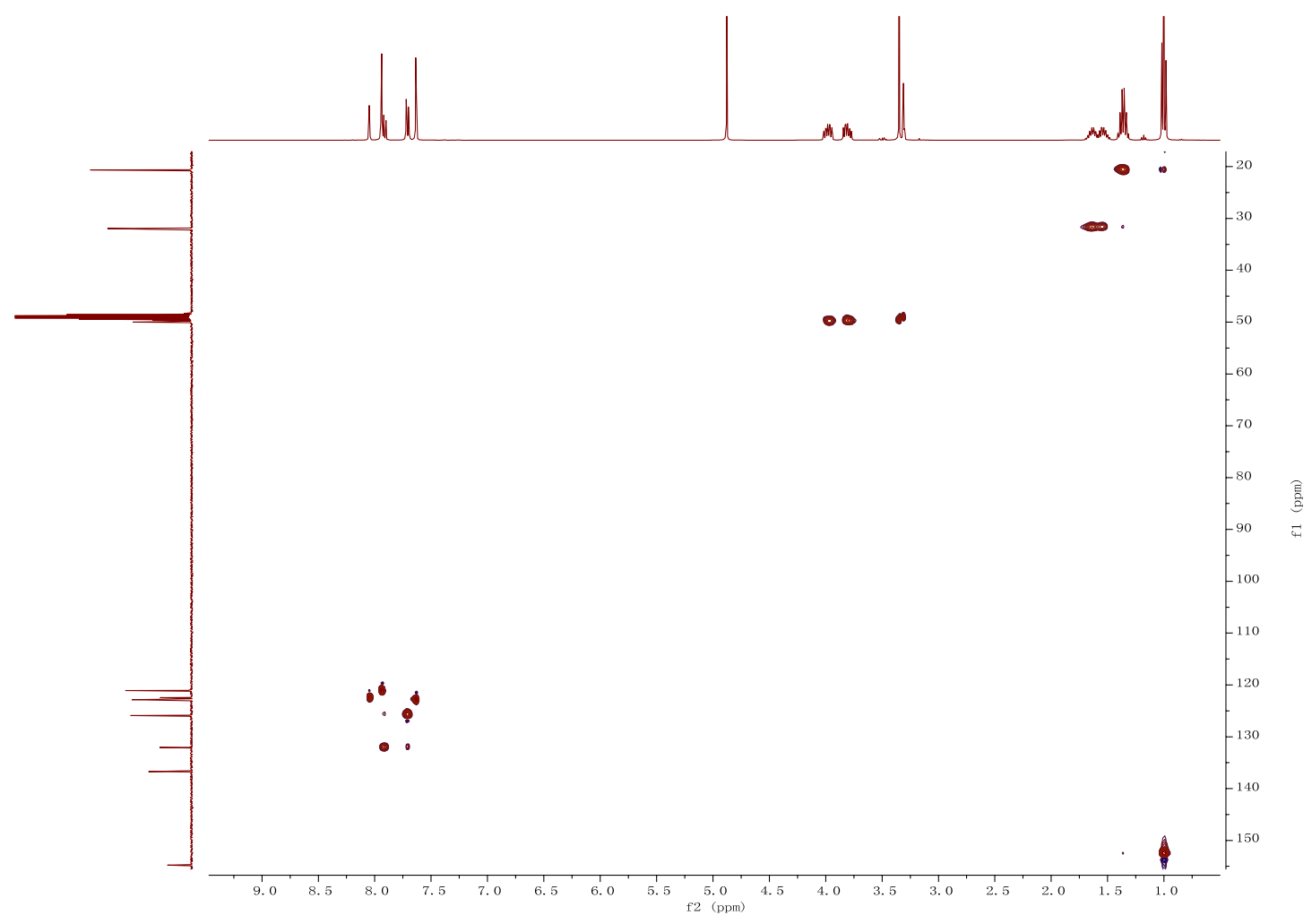

Figure S21. ${ }^{1} \mathrm{H}^{-13} \mathrm{C} \mathrm{HSQC} \mathrm{Spectrum} \mathrm{of} \mathbf{3 b}\left(400 \mathrm{MHz} / 100 \mathrm{MHz}, \mathrm{MeOD}-\mathrm{d}_{4}\right)$

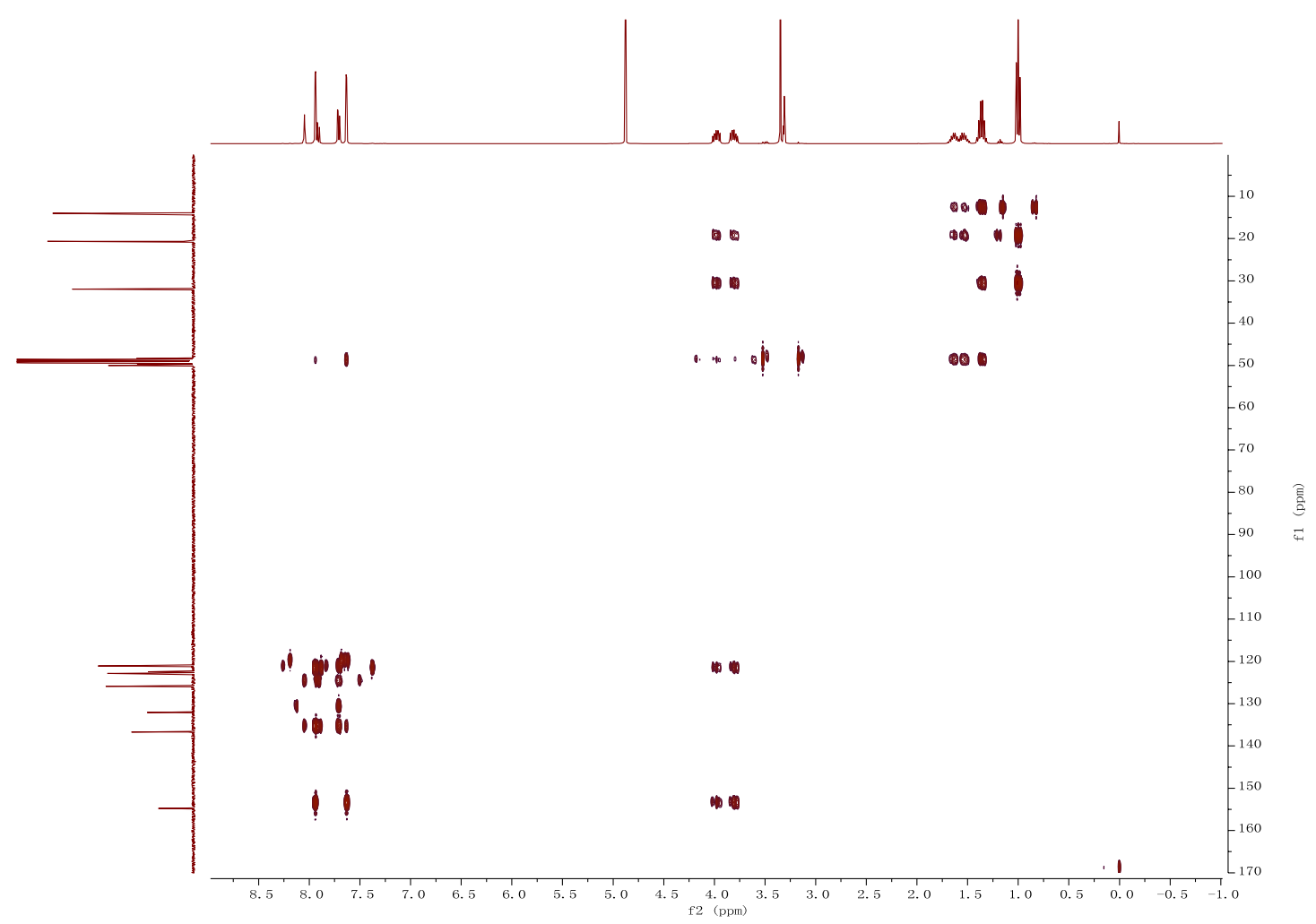

Figure S22. ${ }^{1} \mathrm{H}^{13}{ }^{13} \mathrm{C} \mathrm{HMBC}$ Spectrum of $\mathbf{3 b}\left(400 \mathrm{MHz} / 100 \mathrm{MHz}, \mathrm{MeOD}-\mathrm{d}_{4}\right)$ 


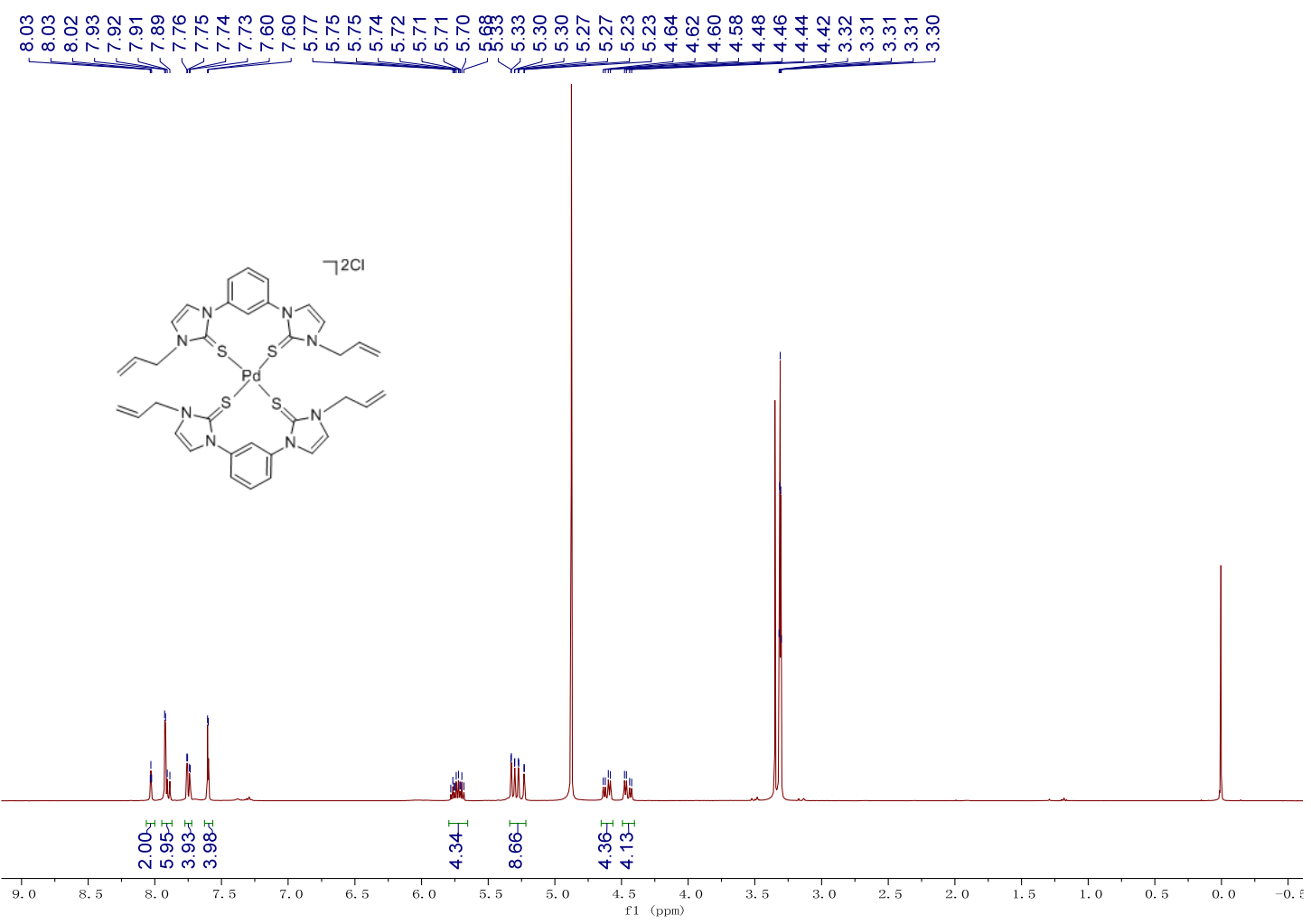

Figure S23. The ${ }^{1} \mathrm{H}$ NMR of $3 c\left(400 \mathrm{MHz}, \mathrm{MeOD}-\mathrm{d}_{4}\right)$
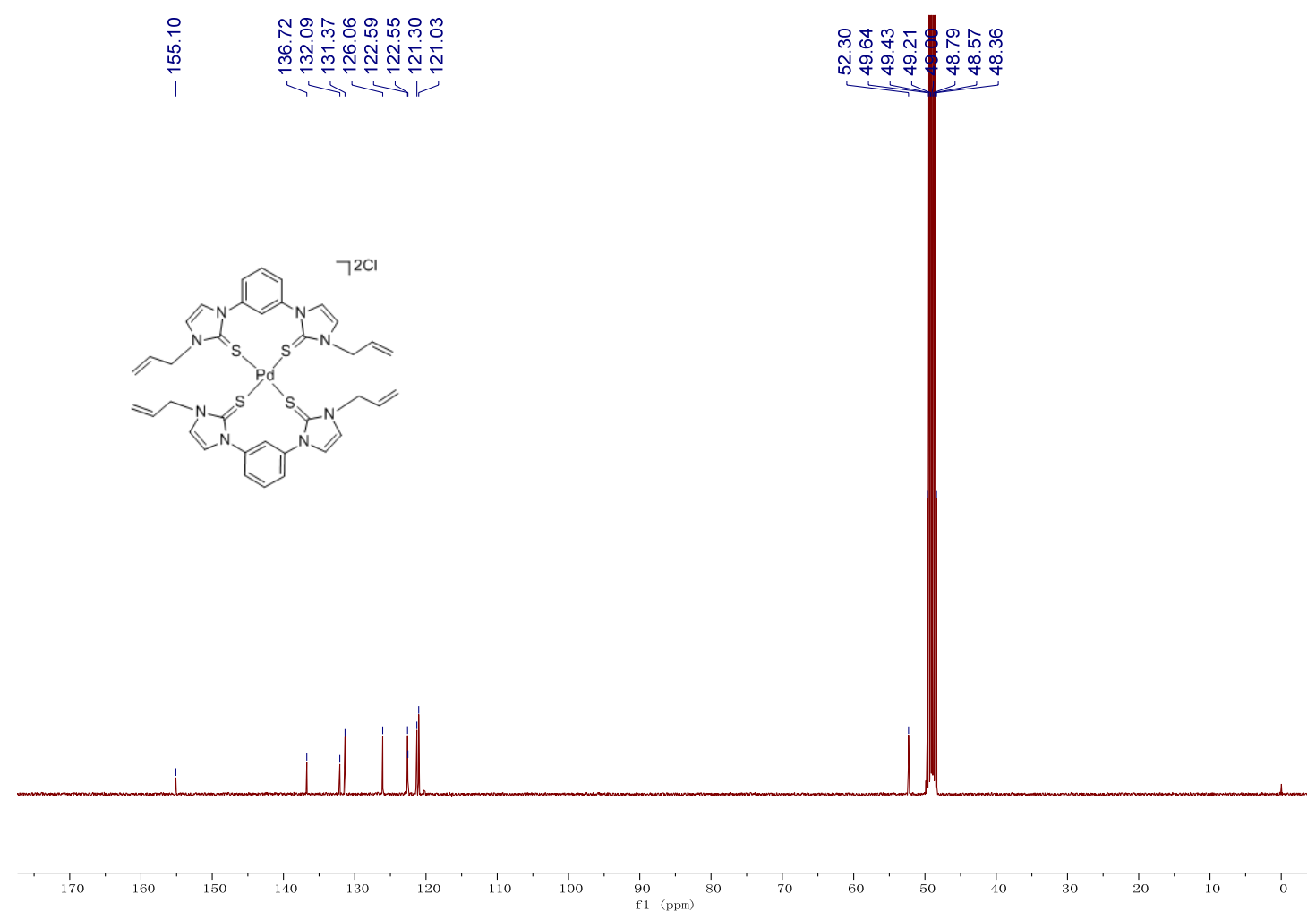

Figure S24. The ${ }^{13} \mathrm{C}$ NMR of $3 \mathrm{c}\left(100 \mathrm{MHz}, \mathrm{MeOD}-\mathrm{d}_{4}\right)$ 


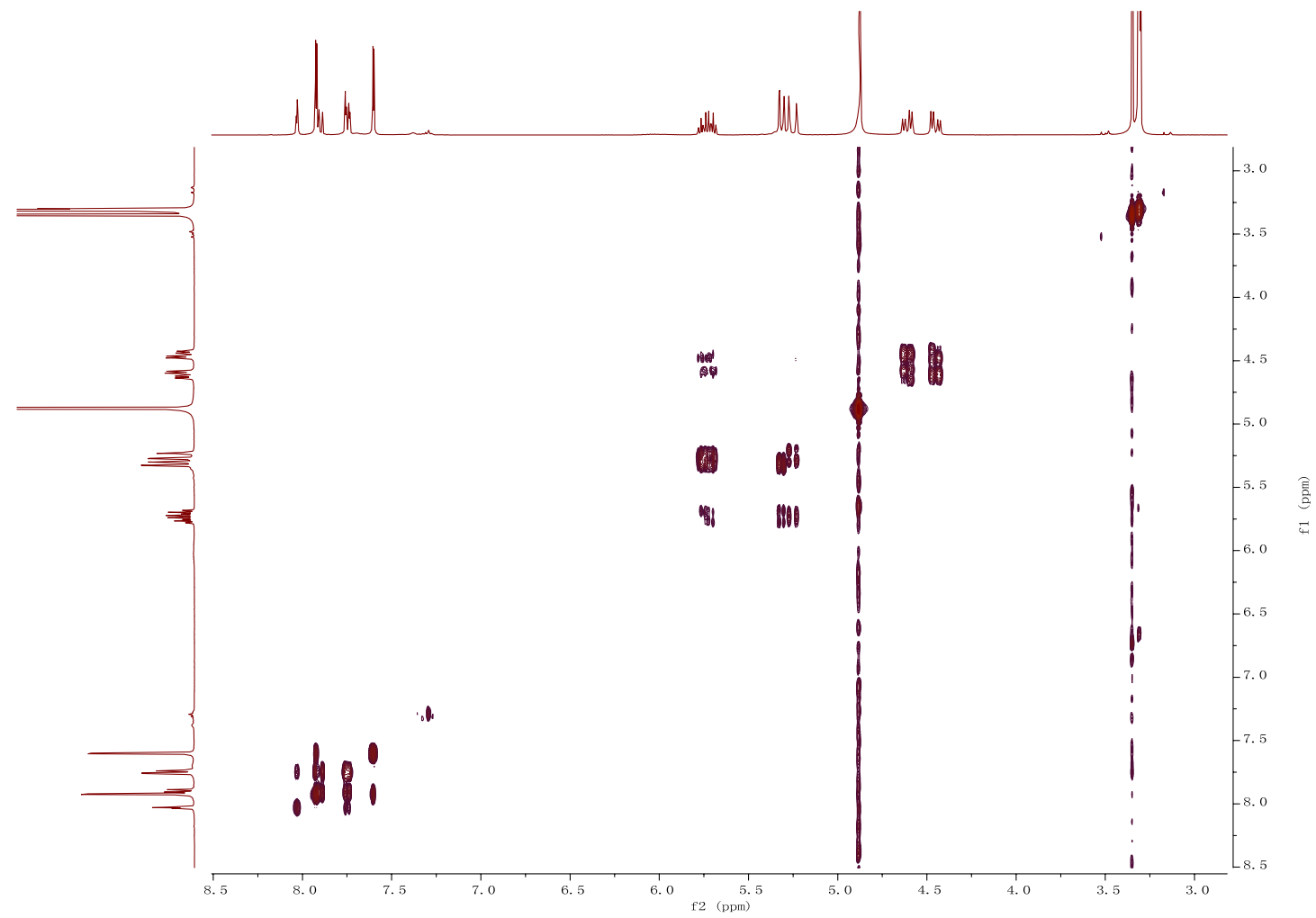

Figure S25. ${ }^{1} \mathrm{H}-{ }^{1} \mathrm{H}$ COSY Spectrum of $3 \mathrm{c}\left(400 \mathrm{MHz}, \mathrm{MeOD}-\mathrm{d}_{4}\right)$

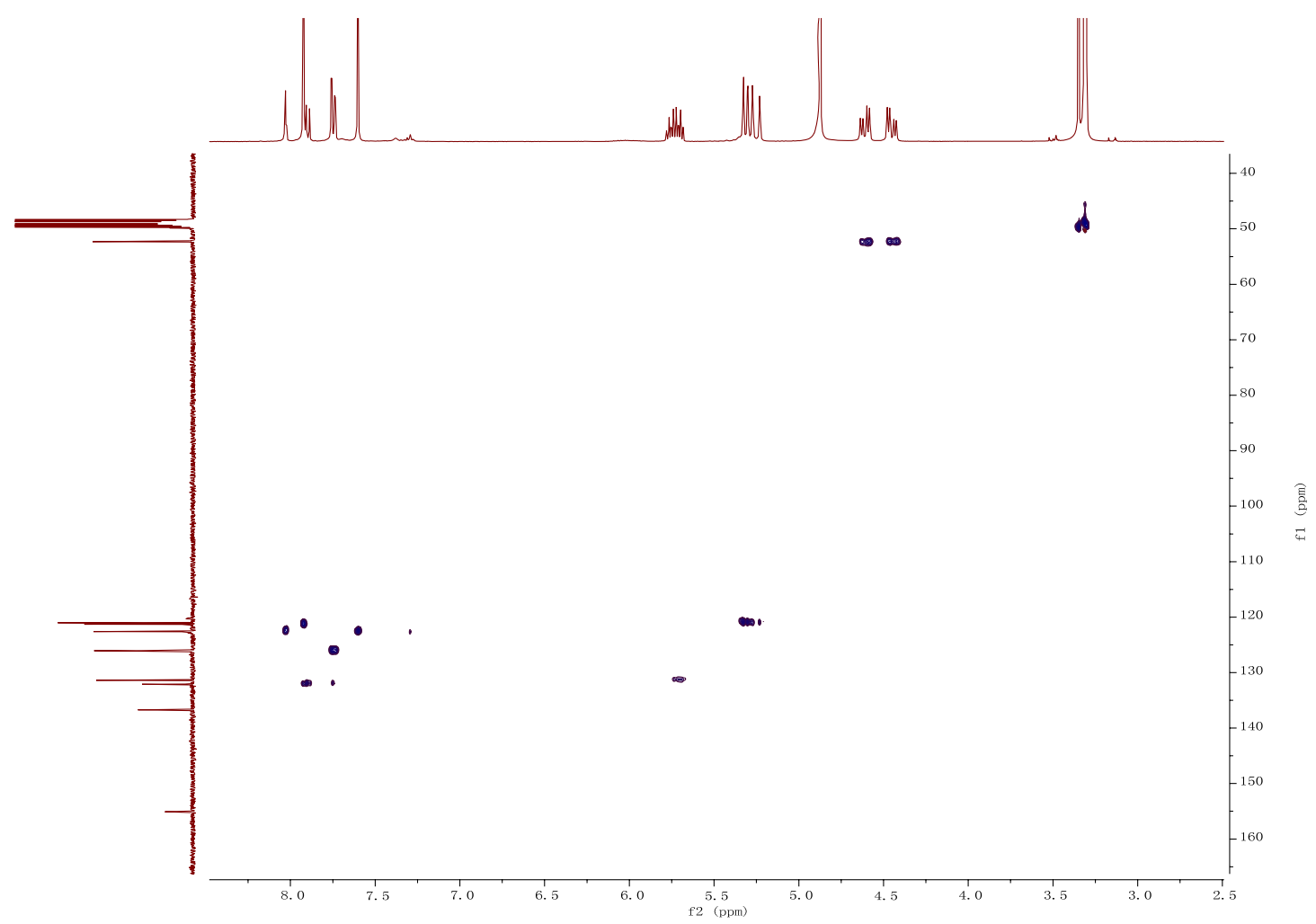

Figure S26. ${ }^{1} \mathrm{H}-{ }^{13} \mathrm{C}$ HSQC Spectrum of $3 \mathrm{c}\left(400 \mathrm{MHz} / 100 \mathrm{MHz}, \mathrm{MeOD}-\mathrm{d}_{4}\right)$ 

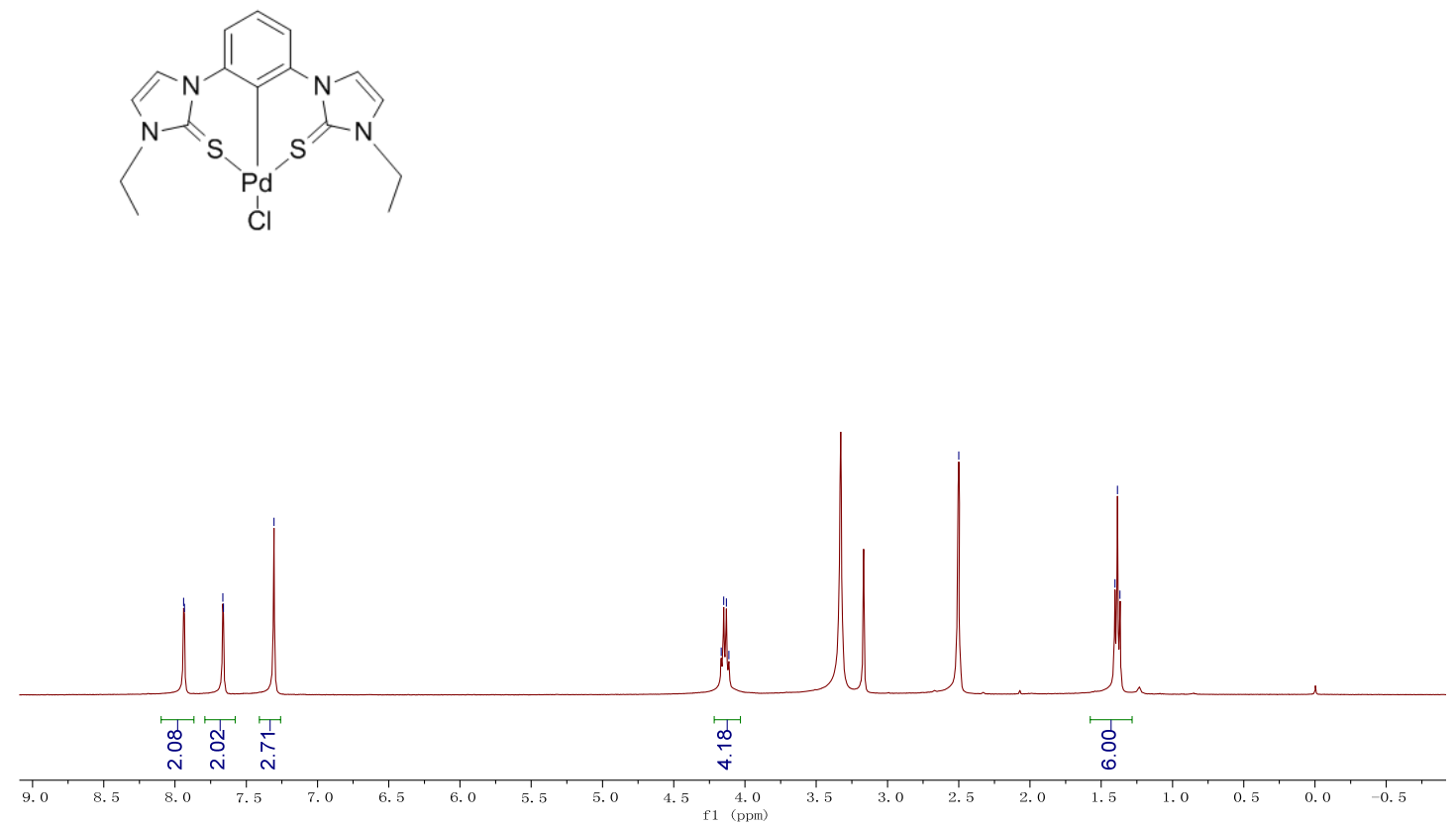

Figure S27. The ${ }^{1} \mathrm{H}$ NMR of $4 a\left(400 \mathrm{MHz}\right.$, DMSO- $\mathrm{d}_{6}$ )
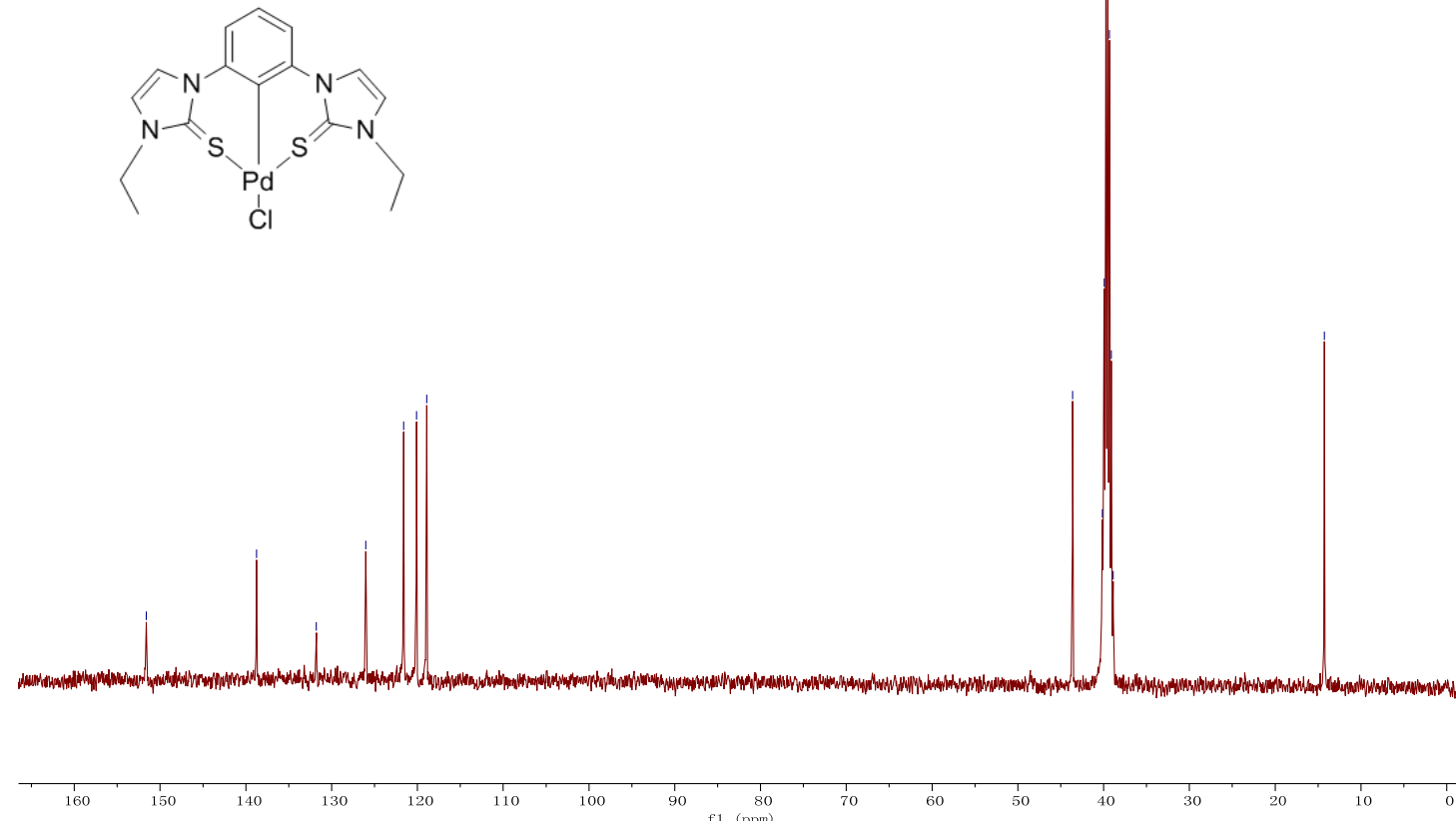

Figure S28. The ${ }^{13} \mathrm{C}$ NMR of $\mathbf{4 a}\left(400 \mathrm{MHz}\right.$, DMSO- $\mathrm{d}_{6}$ ) 


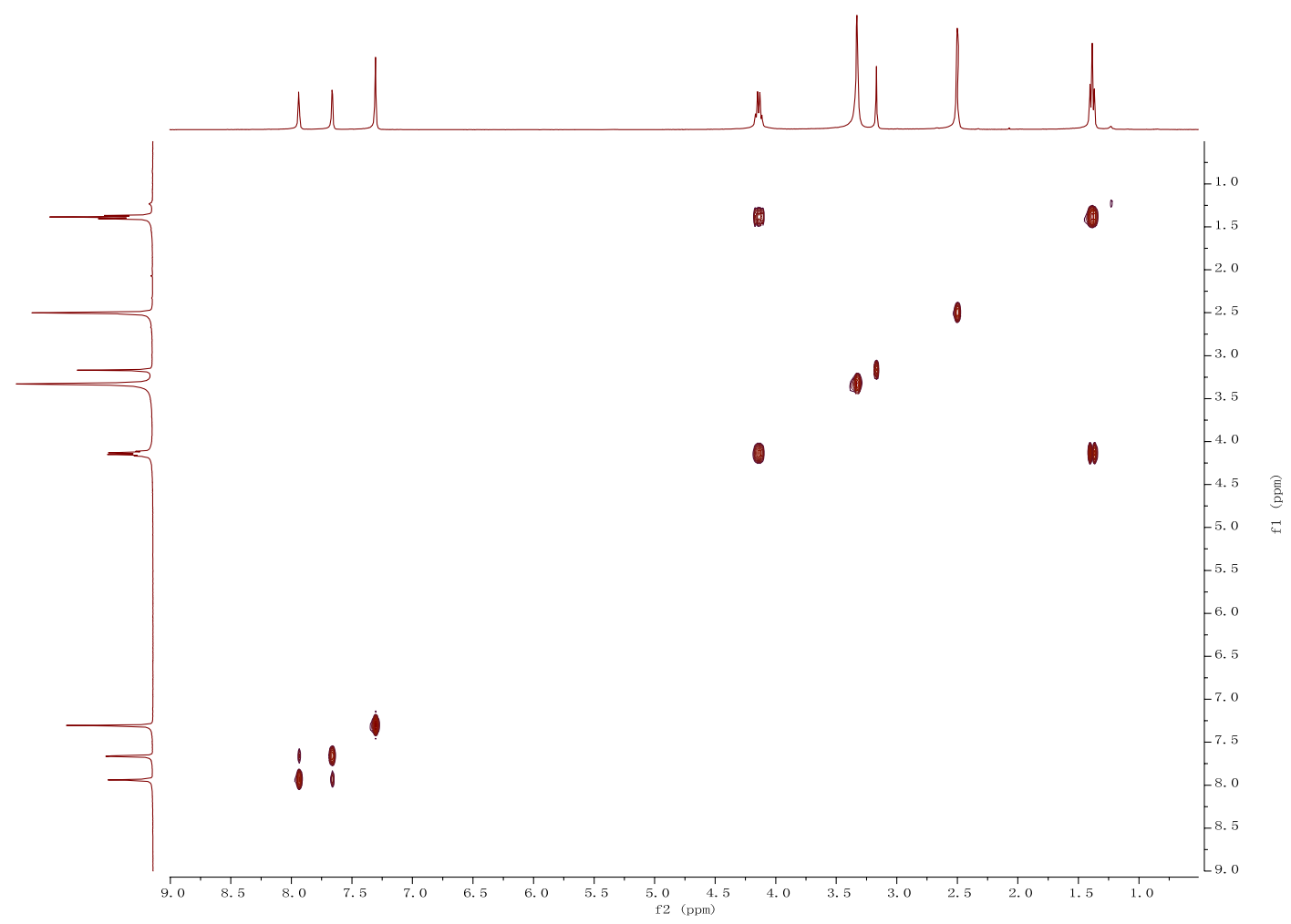

Figure S29. ${ }^{1} \mathrm{H}-{ }^{1} \mathrm{H}$ COSY Spectrum of $4 \mathrm{a}\left(400 \mathrm{MHz}\right.$, DMSO-d $\left.\mathrm{d}_{6}\right)$

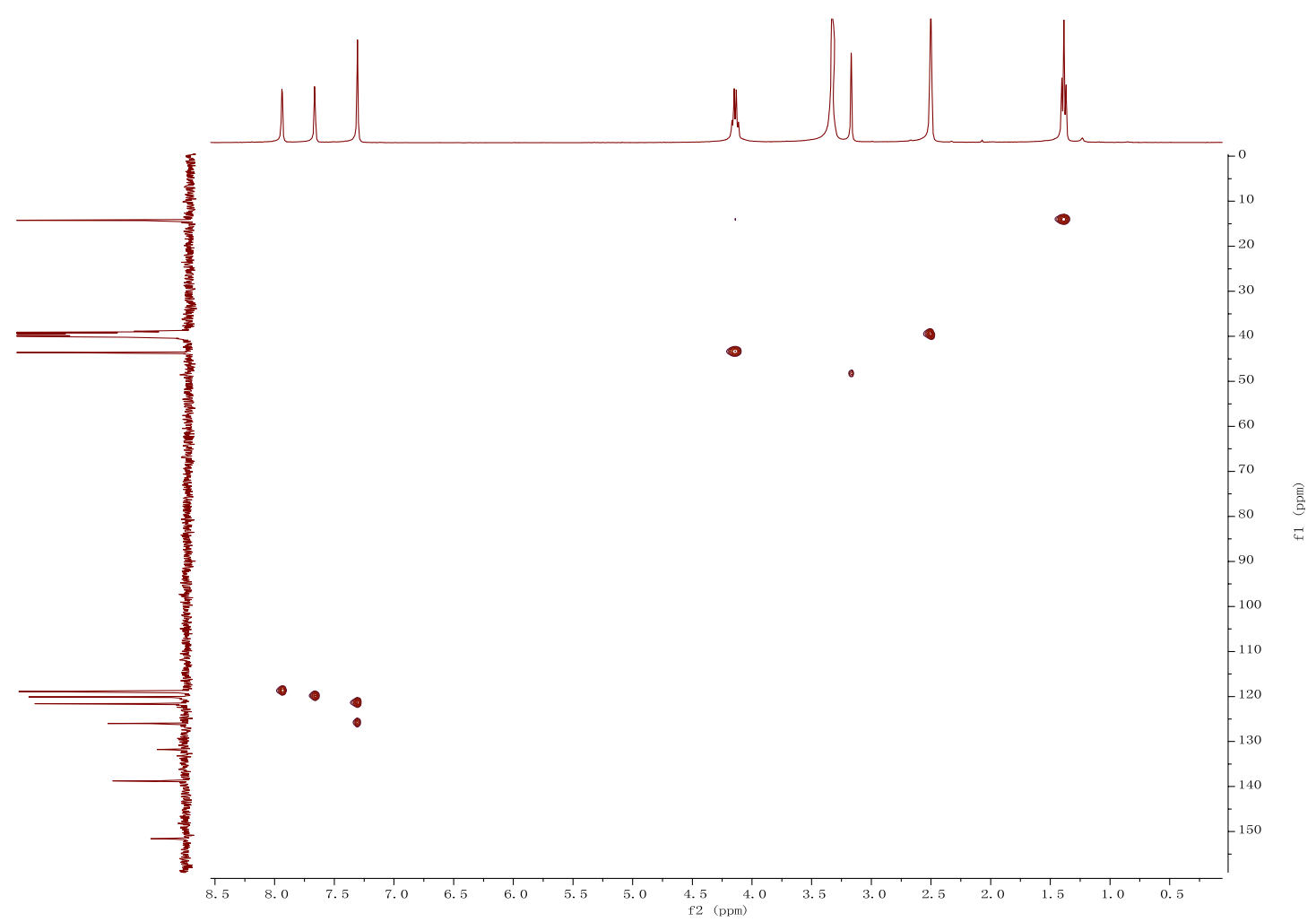

Figure S30. ${ }^{1} \mathrm{H}^{13} \mathrm{C}$ HSQC Spectrum of $4 \mathrm{a}\left(400 \mathrm{MHz} / 100 \mathrm{MHz}, \mathrm{DMSO}-\mathrm{d}_{6}\right.$ ) 


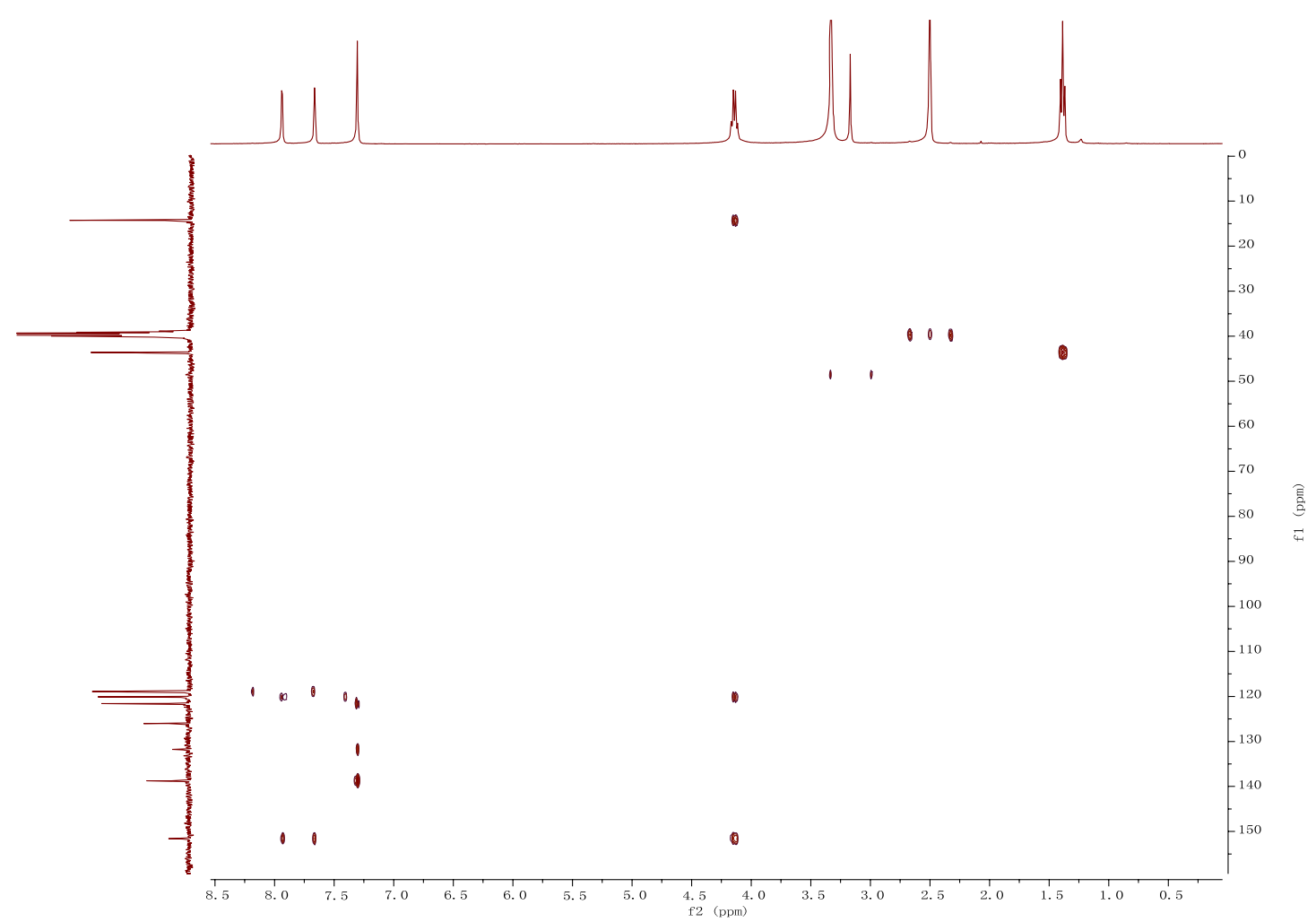

Figure S31. ${ }^{1} \mathrm{H}-{ }^{13} \mathrm{C}$ HMBC Spectrum of $4 a\left(400 \mathrm{MHz} / 100 \mathrm{MHz}, \mathrm{DMSO}-\mathrm{d}_{6}\right.$ )

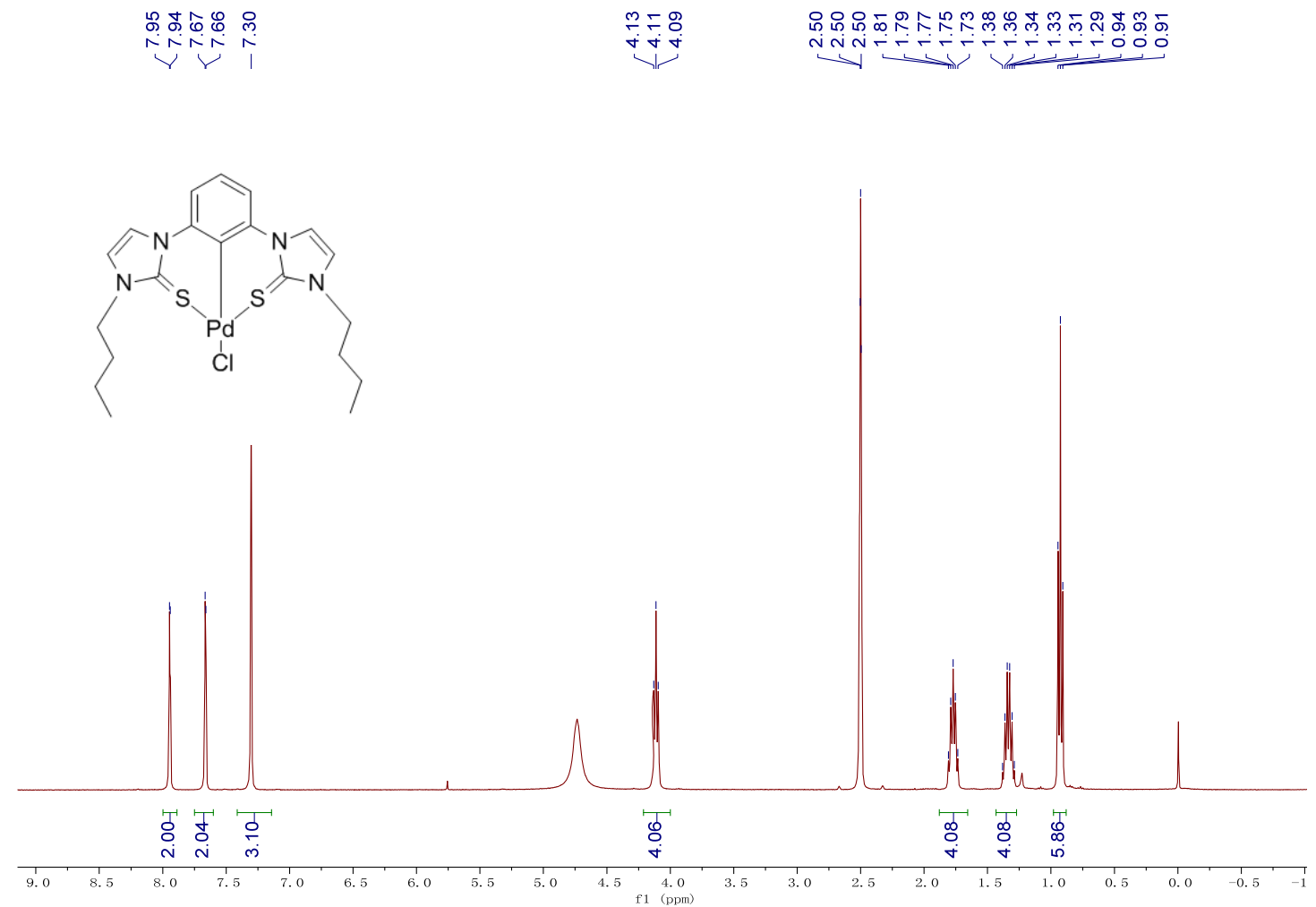

Figure S32. The ${ }^{1} \mathrm{H}$ NMR of $\mathbf{4 b}\left(400 \mathrm{MHz}, \mathrm{DMSO}^{-d_{6}}\right.$ ) 

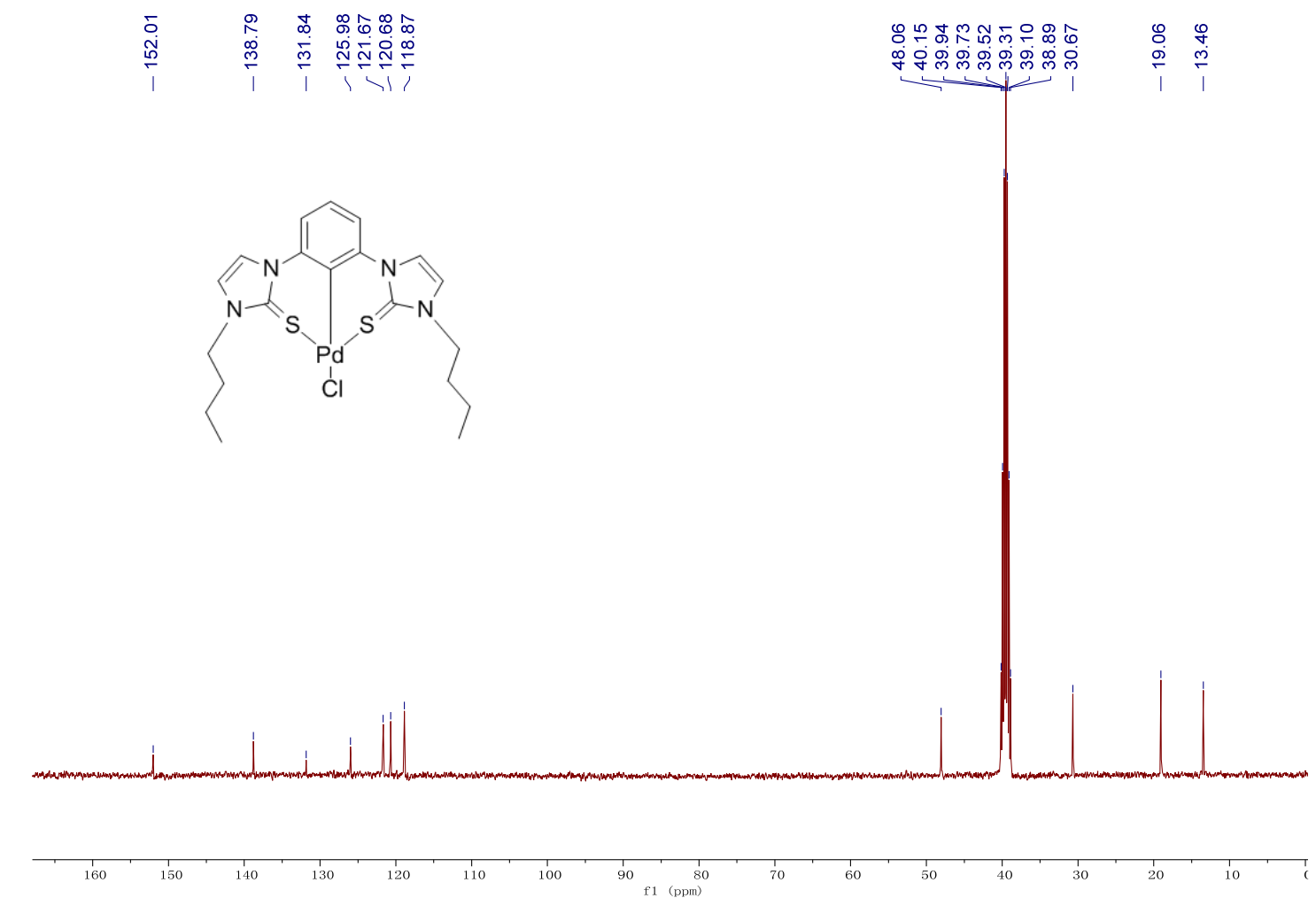

Figure S33. The ${ }^{13} \mathrm{C}$ NMR of $\mathbf{4 b}\left(400 \mathrm{MHz}\right.$, DMSO-d $\left.\mathrm{d}_{6}\right)$

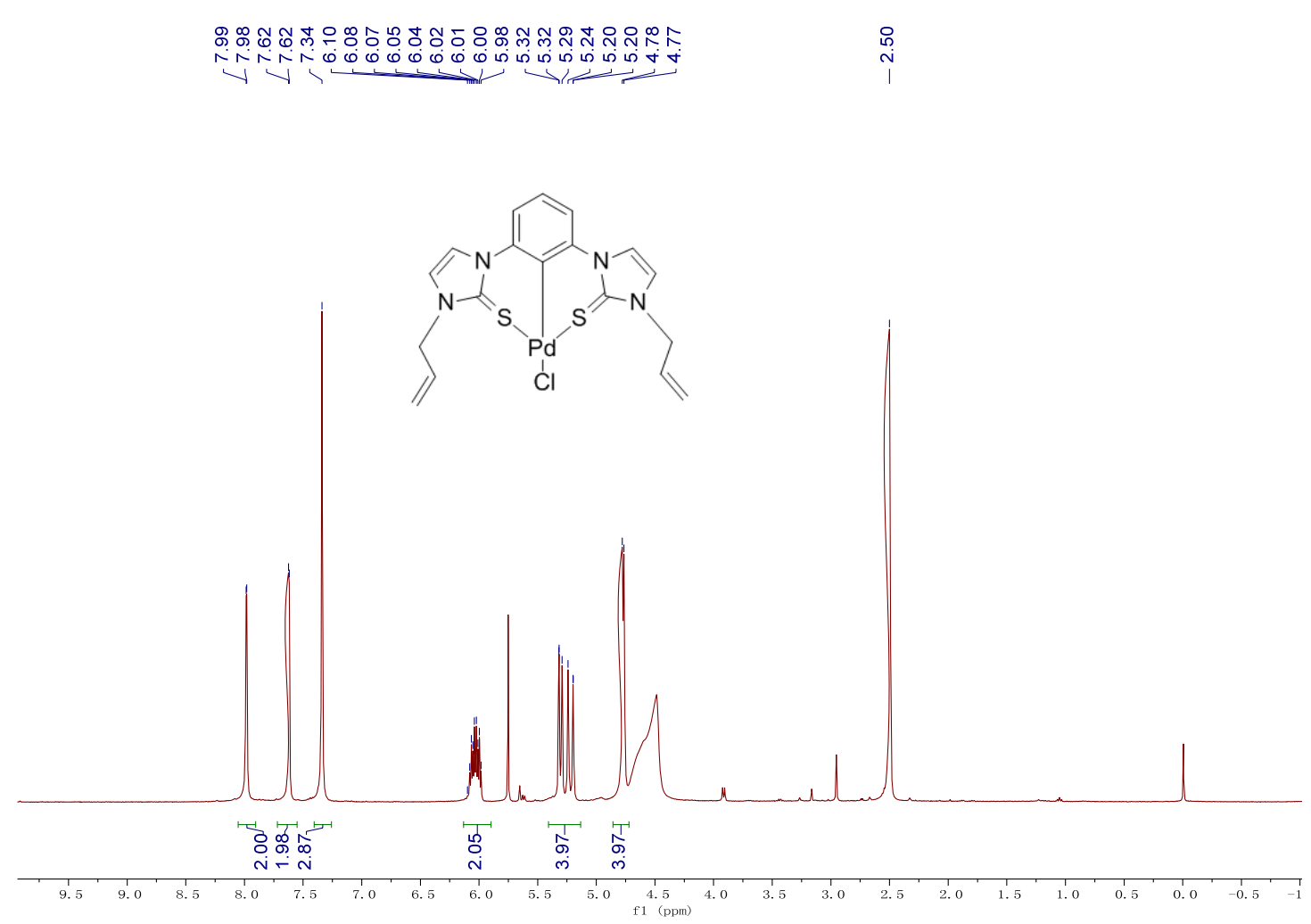

Figure S34. The ${ }^{1} \mathrm{H}$ NMR of $4 \mathbf{c}(400 \mathrm{MHz}$, DMSO-d 6 ) 

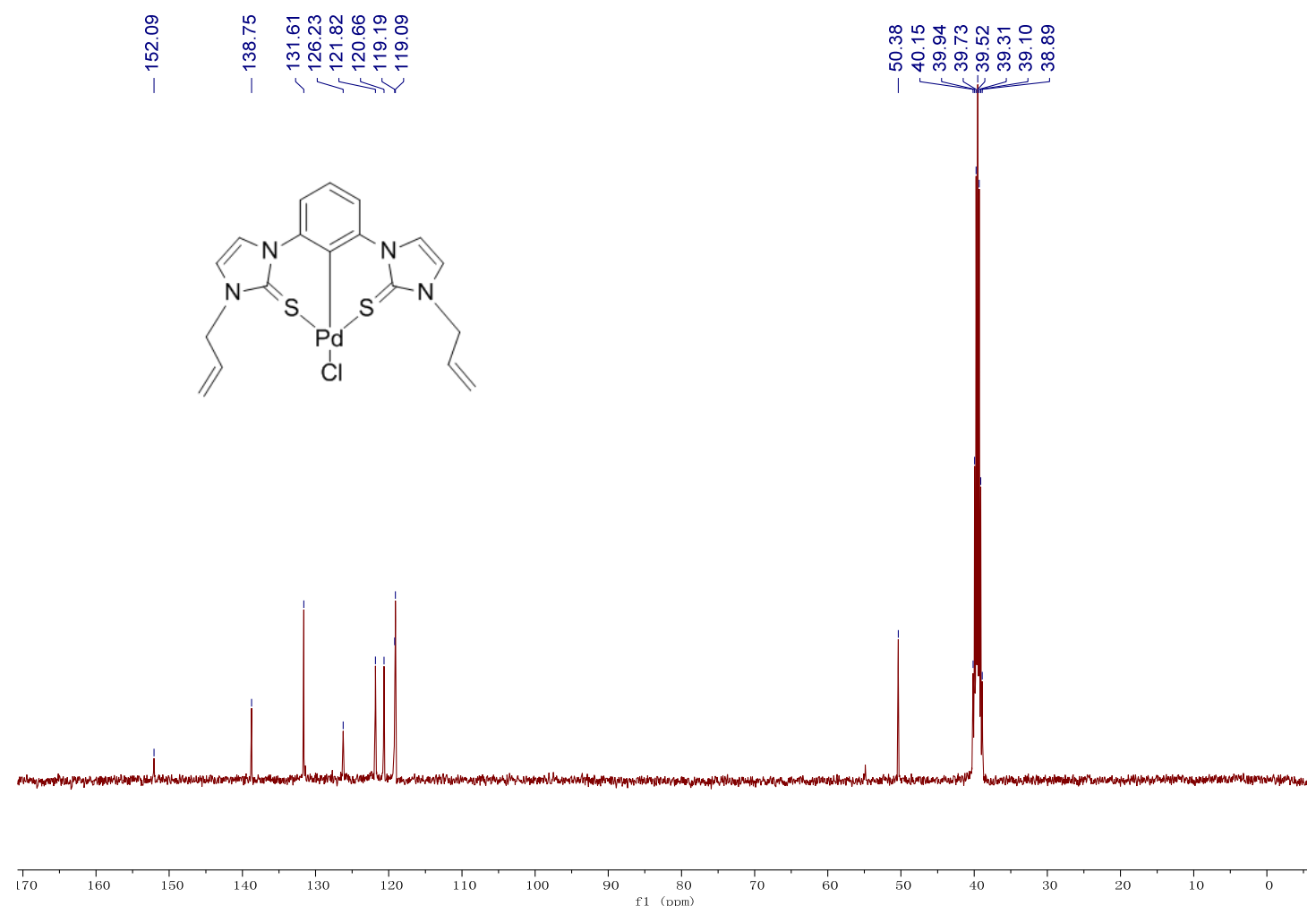

Figure S35. The ${ }^{13} \mathrm{C}$ NMR of $4 \mathrm{c}\left(400 \mathrm{MHz}\right.$, DMSO-d $\left.\mathrm{d}_{6}\right)$

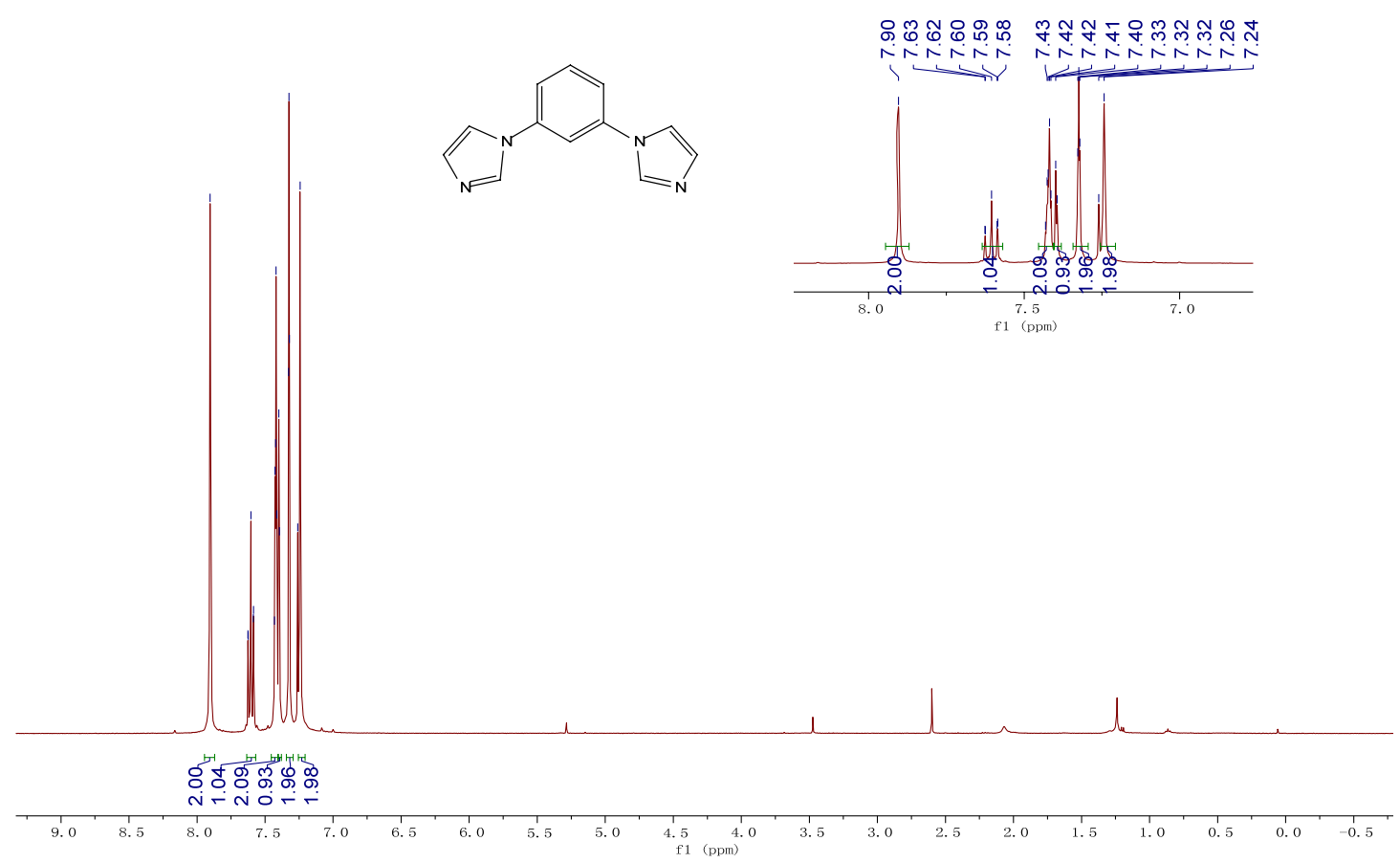

Figure S36. ${ }^{1} \mathrm{H}$ NMR of 1,3-bis(imidazol-1-yl)benzene (400 MHz, $\mathrm{CDCl}_{3}$ ) 


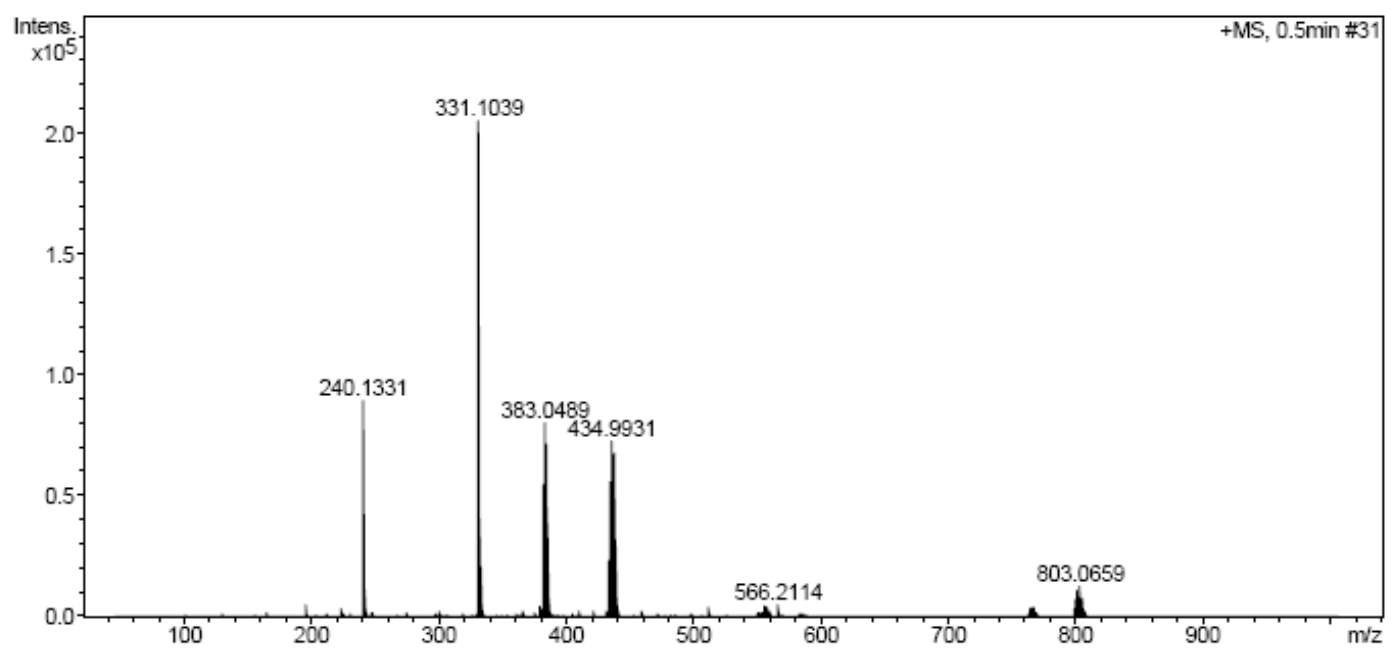

Figure S37. The ESI-MS spectra of complex 3a

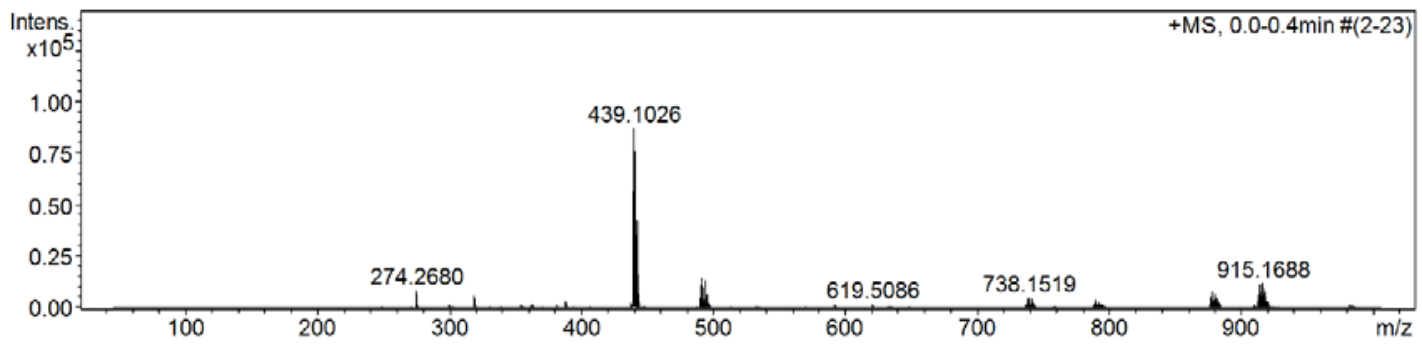

Figure S38. The ESI-MS spectra of complex 3b

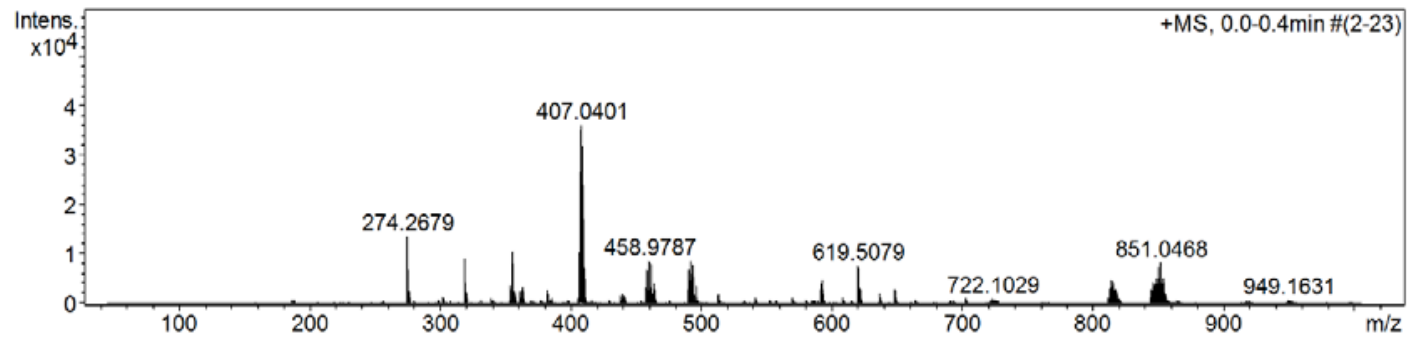

Figure S39. The ESI-MS spectra of complex 3c

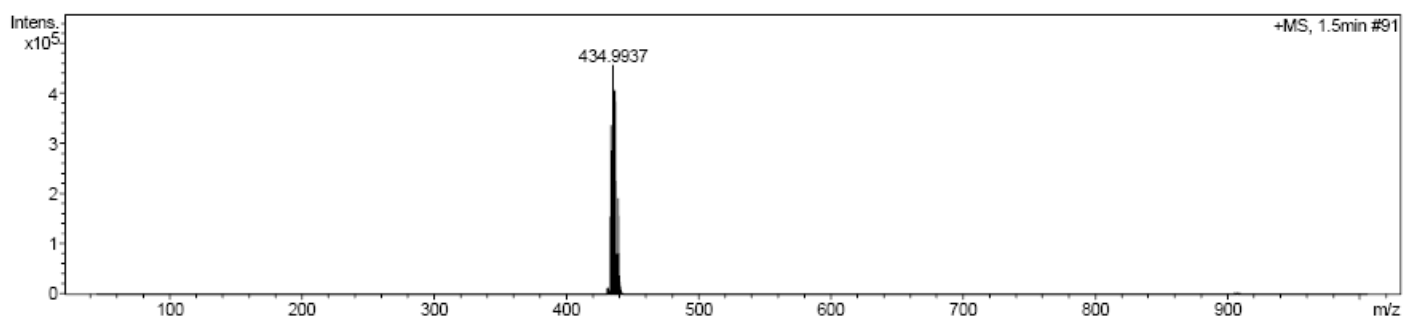

Figure S40. The ESI-MS spectra of complex $\mathbf{4 a}$ 


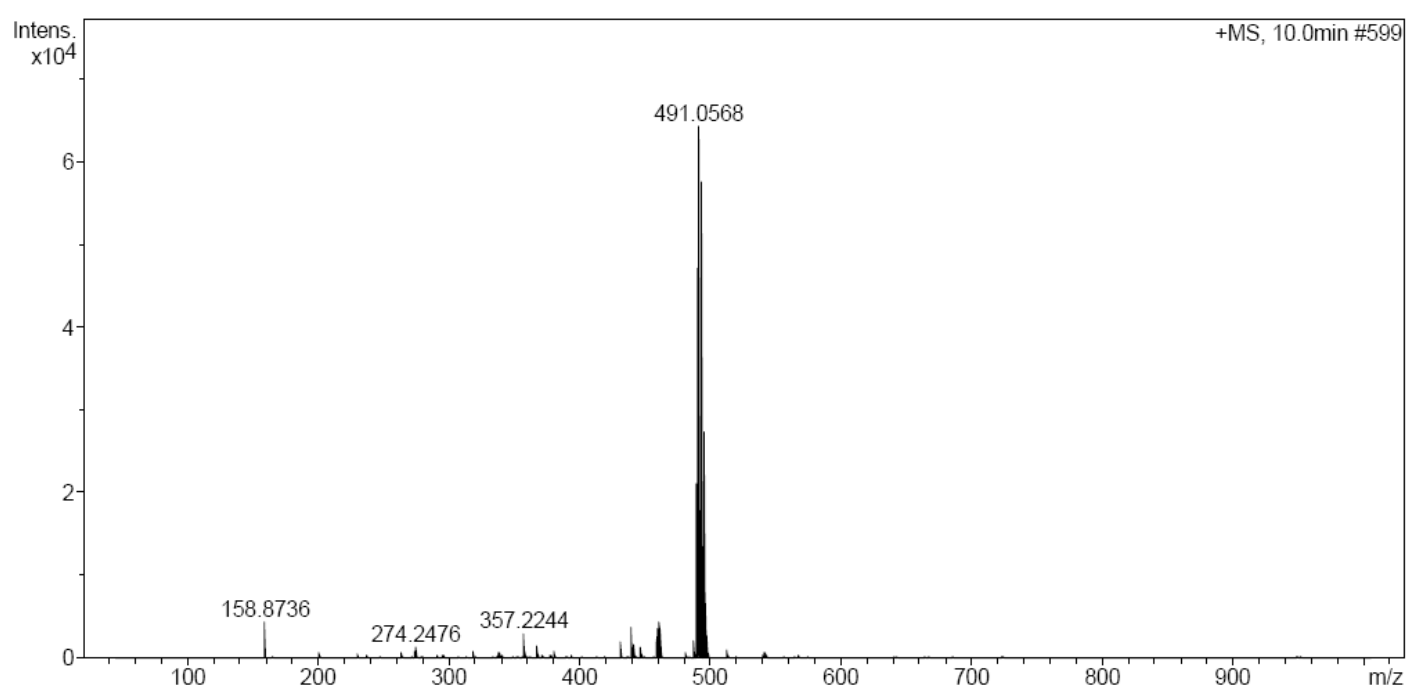

Figure S41. The ESI-MS spectra of complex $\mathbf{4 b}$

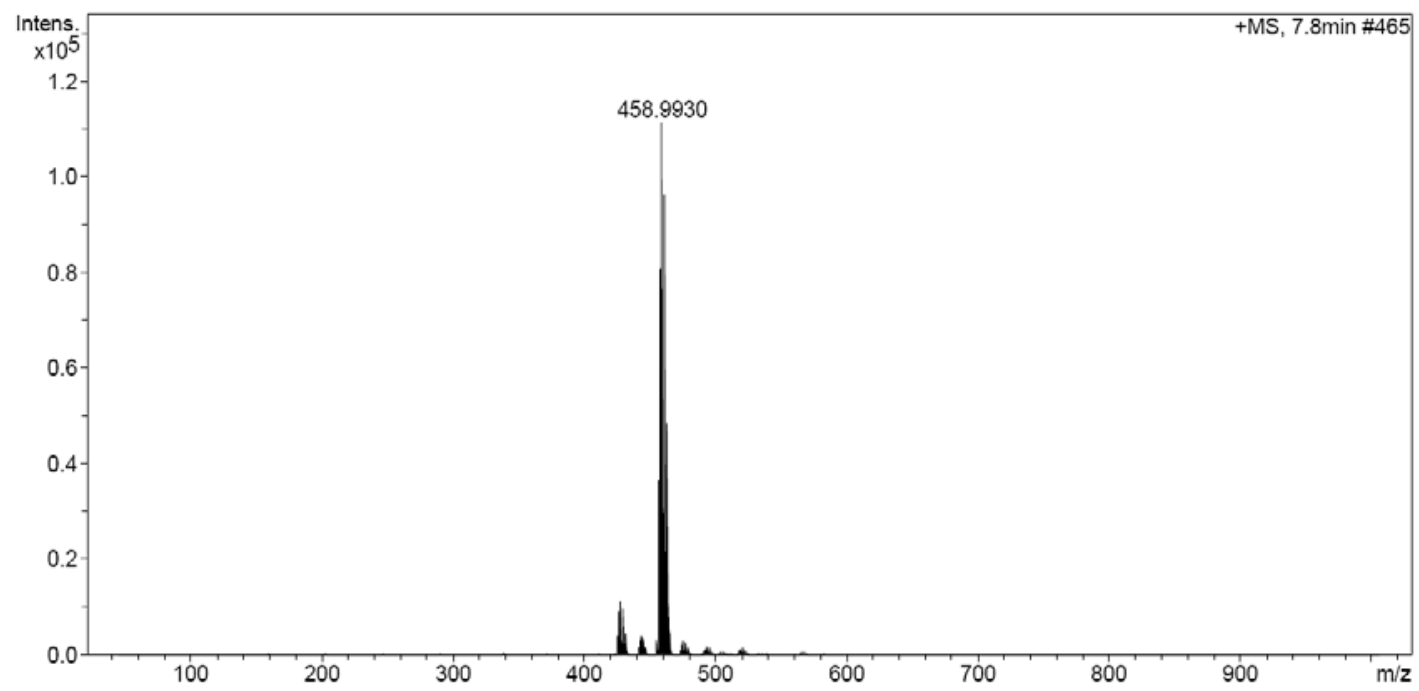

Figure S42. The ESI-MS spectra of complex 4c

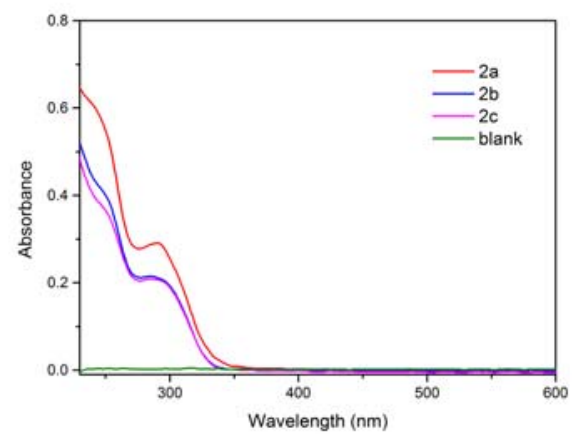

Fig. S43 The absorption of the ligands $\left(2 \times 10^{-5} \mathrm{~mol} / \mathrm{L}\right)$ in $\mathrm{CH}_{2} \mathrm{Cl}_{2} / \mathrm{MeOH}(\mathrm{v} / \mathrm{v}=1: 1)$ at room temperature. 


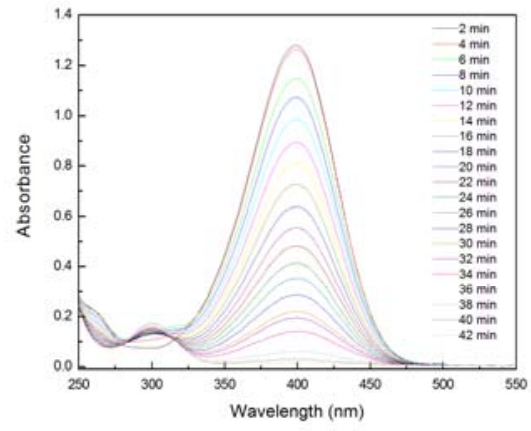

(a)

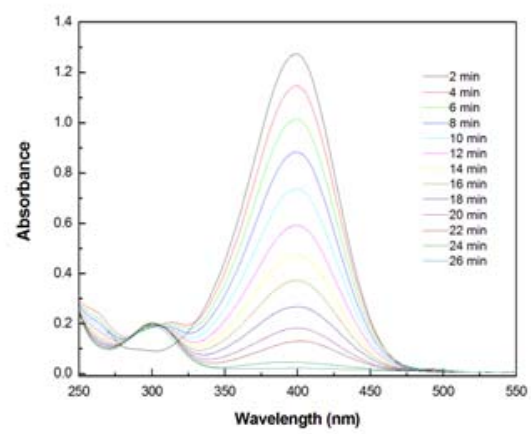

(c)

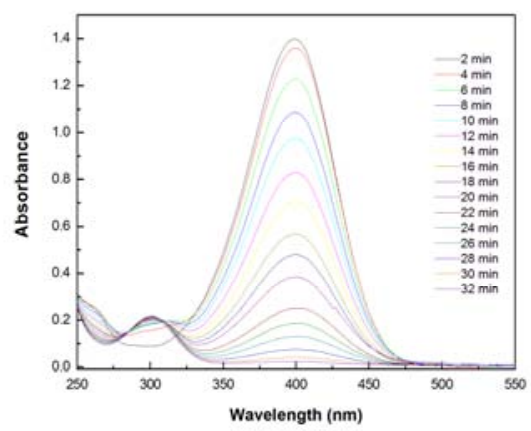

(b)

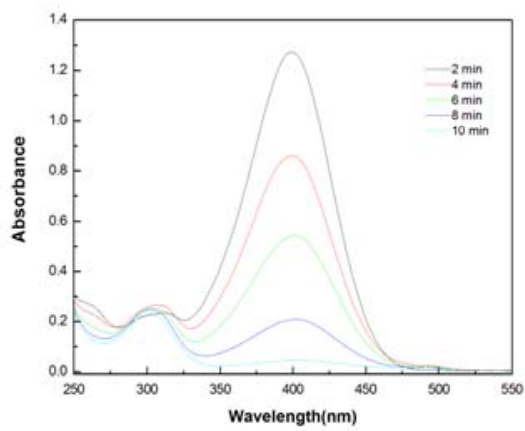

(d)

Figure S44. The loading $0.25 \mathrm{~mol} \%$ (a), $0.5 \mathrm{~mol} \%$ (b), $1 \mathrm{~mol} \%$ (c) and $2 \mathrm{~mol} \%$ (d) of catalyst $\mathbf{4 b}$ for $p$-nitrophenol reduction 